\title{
Fifteen years of the Chinese Continental Scientific Drilling Program
}

\author{
Zhiqin $\mathrm{Xu}^{1,2}$, Jingsui Yang ${ }^{2}$, Chengshan Wang ${ }^{3}$, Zhisheng $\mathrm{An}^{4}$, Haibing $\mathrm{Li}^{2}$, Qin Wang ${ }^{1}$, and Dechen $\mathrm{Su}^{2}$ \\ ${ }^{1}$ State Key Laboratory for Mineral Deposits Research, School of Earth Sciences and Engineering, Nanjing \\ University, Nanjing 210023, China \\ ${ }^{2}$ Laboratory for Continental Tectonics and Dynamics, Institute of Geology, Chinese Academy of Geological \\ Sciences, Beijing 100037, China \\ ${ }^{3}$ School of Earth Sciences and Resources, China University of Geosciences, Beijing 100083, China \\ ${ }^{4}$ State Key Laboratory of Loess and Quaternary Geology, Institute of Earth Environment, Chinese Academy of \\ Sciences, Xi'an 710061, China \\ Correspondence to: Qin Wang (qwang@ @ju.edu.cn) and Dechen Su (sudechen@163.com)
}

Received: 24 October 2016 - Revised: 10 March 2017 - Accepted: 13 March 2017 - Published: 31 May 2017

\begin{abstract}
Continental scientific drilling can be regarded as "a telescope into the Earth's interior" because it provides process insight and uncompromised samples of rocks, fluids, and even sampled from the deep biosphere from the Earth's surface to great depths. As one of the three founding members of the International Continental Scientific Drilling Program (ICDP), ICDP China has made great achievements in many scientific drilling-related research fields. Based on the ICDP participation it attracted global attention of scientists and set up not only the Chinese Continental Scientific Drilling (CCSD) Program in 2001 but also a growing number of ambitious drilling projects in the country.

The $5158 \mathrm{~m}$ deep borehole of the CCSD project at Donghai County in the Sulu ultrahigh-pressure metamorphic terrain demonstrates that large amounts of crustal rocks of the South China Block have been subducted to at least $120 \mathrm{~km}$, followed by rapid uplift. After successful completion of drilling at Donghai, several continental scientific drilling projects were conducted with funding of the Chinese government and partially with support of ICDP, resulting in a total drilling depth of more than $35000 \mathrm{~m}$. These projects encompass the Continental Environmental Scientific Drilling Program of China, the Scientific Drilling Project of Wenchuan Earthquake Fault Zone, the Continental Scientific Drilling Project of Cretaceous Songliao Basin, and the Program of Selected Continental Scientific Drilling and Experiments. On the occasion of the 20th anniversary of the ICDP and the 15th anniversary of the CCSD Program, this paper reviews the history and major progress of the CCSD Program.
\end{abstract}

\section{Introduction}

Flying into the outer space, going into the Earth's interior, and investigating the deep ocean floor have been dreams of mankind for the exploration of the nature. Numerous exploration projects to the space and the ocean floor have been carried out since 1950s. Twenty years have passed since the foundation of the International Continental Scientific Drilling Program (ICDP) in 1996. Symbolized as "a telescope into the Earth's interior", the ICDP aims to provide fresh samples from great depths to reveal the complex com- position and structure of the continental crust, the Earth's fluid system, microbiological distribution, geothermal energy, and earthquake mechanisms. Chinese scientists were involved in many ICDP projects and contributed to the success of the ICDP in many research fields.

The ICDP only supports projects that address fundamental scientific issues of global significance. One of the most exciting discoveries in the last 3 decades is the global distribution of coesite- and diamond-bearing ultrahigh-pressure (UHP) metamorphic terranes, demonstrating that low-density continental material could be rapidly subducted to depths greater 
than $100 \mathrm{~km}$ and then exhumed to the surface (Zheng, 2012; Hermann and Rubatto, 2014; Liou et al., 2014). Hence, continental subduction played a critical role in plate tectonics and material recycling between the crust and the upper mantle. Since the discovery of coesite and microdiamond from eclogites and their country rocks in the Dabie Mountains (Okay et al., 1989; Wang et al., 1989; Xu et al., 1992), extensive studies have shown that the Dabie-Sulu orogenic belt is one of the largest $\left(\sim 30000 \mathrm{~km}^{2}\right)$ and best exposed UHP metamorphic terranes in the world (Liou et al., 2014). As the first ICDP project in China, the Chinese Continental Scientific Drilling (CCSD) project began to drill the $5158 \mathrm{~m}$ deep borehole in Donghai County (Jiangsu Province) on 4 August 2001, which marked the starting point of the CCSD Program (Xu et al., 2009a).

Uplift of the Tibetan Plateau in the Cenozoic has had profound influence on the global climate change and inland aridification. In order to study the evolution of Asian monsoon and its relationship with regional tectonics and global climate change, the Lake Qinghai Drilling Project was conducted in 2005 to obtain high-quality geological and biological core records (An et al., 2006, 2012). On 12 May 2008, the $M_{\mathrm{w}} 7.9$ Wenchuan earthquake happened along the Longmenshan thrust belt in the eastern margin of the Tibetan Plateau. In order to better understand the intracontinental earthquake mechanisms, Chinese scientists started the Wenchuan earthquake Fault Scientific Drilling (WFSD) project just 178 days after the earthquake (Li et al., 2013, 2014). The ongoing Continental Scientific Drilling Project of Cretaceous Songliao Basin started in April 2014 and will recover continuous highresolution terrestrial achieves and Cretaceous climate change (Wang et al., 2008, 2013a, b). Besides these ICDP projects, from 2008 to 2012 the Chinese government also supported the Program of Selected Continental Scientific Drilling and Experiments, which consists of seven drilling projects on some key problems in continental dynamics. These projects provided scientific and technical preparation for the future superdeep borehole (over $10000 \mathrm{~m}$ ) in China.

On the occasion of the 20th anniversary of the ICDP and the 15th anniversary of the CCSD Program, we present a brief review of history and achievements of the CCSD Program.

\section{The Chinese Continental Scientific Drilling project}

\subsection{History of the CCSD project}

Preparation for the CCSD project can be traced back to 1988 . Encouraged by the drilling projects of the Kola superdeep borehole and the Kontinentales Tiefbohrprogramm der Bundesrepublik Deutschland (KTB), Chinese scientists proposed a continental scientific drilling plan in mainland China in 1988. The Ministry of Geology and Mineral Resources of China, which was combined in the Ministry of Land Resources of China in 1998, started to investigate potential sci- entific drilling sites in 1991. After years of investigation and discussion, China founded the ICDP with Germany and the United States in February 1996. In July 1996, Chinese scientists hosted the ICDP workshop in Qingdao, eastern China, and proposed three UHP localities in the Dabie-Sulu orogenic belt from Jiangsu, Anhui, and Shandong provinces. Based on outcrops of UHP metamorphic rocks, seismic profiles, shallow boreholes, and technical feasibility, the Science Advisory Group of the ICDP agreed to select Maobei village in Donghai County (Jiangsu Province) as the drilling site of the CCSD project.

In June 1997, the CCSD project was listed as one of major scientific projects in the Ninth Five-Year Plan of China. This was an important step to get financial support from Chinese government. The first pre-pilot borehole CCSD-PP1 in the Zhimafang ultramafic massif in Donghai County was accomplished at a depth of $432 \mathrm{~m}$ in November 1997. Then in April 1998, the ICDP passed the drilling proposal of the CCSD project and funded USD 1.5 million in the form of drilling facilities. Drilling of the second pre-pilot borehole CCSD-PP2 at Maobei village in Donghai County started in December 1998, and reached a depth of $1028.68 \mathrm{~m}$ in June 1999. The CCSD-PP2 was the first scientific borehole with complete sampling and logging in China, and succeeded in core recovery of $92.8 \%$. Chinese engineers and technicians also used the CCSD-PP2 to test different drilling techniques and materials, as well as on-site measurements. In September 1999, Chinese government agreed the budget of the CCSD project. As the largest and most expensive geoscientific research project ever undertaken in China before 2005, the total cost of the CCSD project was CNY 176 million (about USD 21.3 million).

The CCSD project was the first scientific drilling project in an UHP terrane. The ICDP provided important help by inviting Chinese scientists and engineers to visit the KTB and attend training courses. Test of all drilling facilities and onsite measurements for the CCSD main borehole (CCSD-MH) began on 25 June 2001. Experts from the ICDP came to the drilling site at Maobei village to provide technical support. Chinese engineers developed new drilling and core recovery tools. With funding from the Ministry of Science and Technology, the Ministry of Land and Resources, the National Natural Science Foundation of China and the ICDP, the CCSD-MH was drilled to a depth of $5158 \mathrm{~m}$ from 4 August 2001 to 8 March 2005 (Fig. 1). The average core recovery of the CCSD-MH reaches $85.7 \%$. Meanwhile, the third prepilot borehole CCSD-PP3 penetrated $705 \mathrm{~m}$ into the Gangshang ultramafic massif in Ganyu County, with about $90 \%$ core recovery.

The principal investigator (PI) of the CCSD project was Chinese Academician Zhiqin $\mathrm{Xu}$, and the drilling project leader was Da Wang, a professor and senior engineer from the Geological Survey of China. More than 2000 people were involved in the CCSD project, including about 120 Chinese 


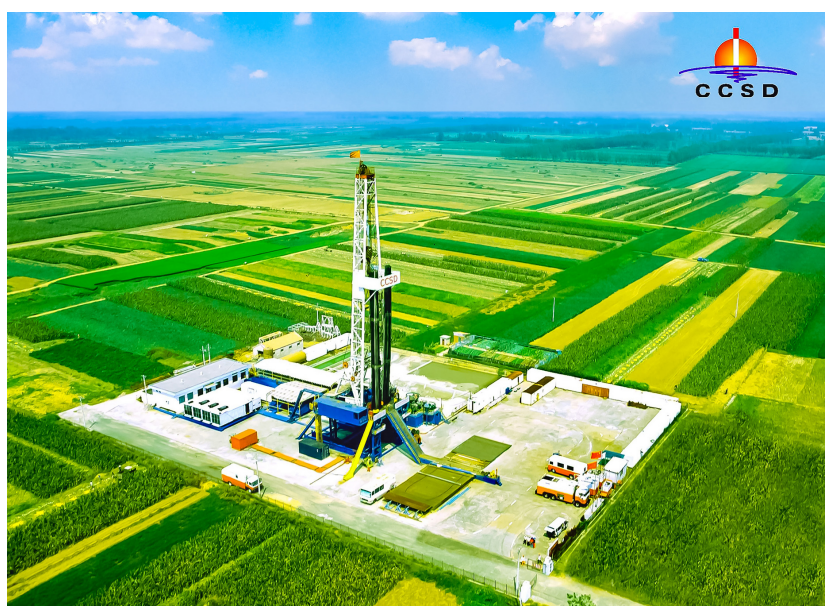

Figure 1. Drilling site of the CCSD-MH at Maobei village in Donghai County, Jiangsu Province, eastern China.

scientists and technicians and 30 scientists from the United States, Germany, France, and Japan.

\subsection{Geological background and scientific objectives of the CCSD project}

The Dabie-Sulu orogenic belt was formed by northward subduction of the South China Block beneath the North China Block in the Triassic, and was then separated by the leftlateral strike-slip Tan-Lu fault into the Dabie Mountains in the west and the Sulu Terrane in the east (Fig. 2) (e.g., Cong, 1996; Xu et al., 2009a). The wide occurrence of coesite, microdiamond, UHP hydrous phases, and exsolution textures in eclogites, garnet peridotites, and their supracrustal country rocks indicates that the South China Block has been subducted to depths $>120 \mathrm{~km}$ at extremely low geotherms (for review see Liou et al., 2009). Most UHP metamorphic rocks in the Dabie-Sulu orogenic belt yield the Neoproterozoic protolith ages of 780-740 Ma and extremely low $\delta^{18} \mathrm{O}$ values, which suggests their tectonic affinity to the South China Block (Zheng, 2008, and references therein). It is generally believed that the UHP metamorphism in the Dabie-Sulu orogenic belt occurred in the Triassic, but different methods result in large variations: $\sim 245 \mathrm{Ma}$ from zircon $\mathrm{U}-\mathrm{Pb}$ ages (Hacker et al., 1998) or $226 \pm 2 \mathrm{Ma}$ from a mineral Sm-Nd isochron dating ( $\mathrm{Li}$ et al., 2000). Sensitive high-resolution ion microprobe (SHRIMP) $\mathrm{U}-\mathrm{Pb}$ dating on coesite-bearing domains of metamorphic zircon bracketed the UHP metamorphism between 240 and $225 \mathrm{Ma}$, and the amphibolite facies retrogression between 215 and $205 \mathrm{Ma}$ (e.g., Liu et al., 2004a, b, 2006; Wu et al., 2006). This suggests that the subducted crustal rocks experienced a rapid syn-collisional exhumation at mantle depths.

Both the Dabie Mountains and the Sulu Terrane consist of a series of high-pressure (HP) and UHP metamorphic slices bounded by ductile shear zones (Fig. 2a). The

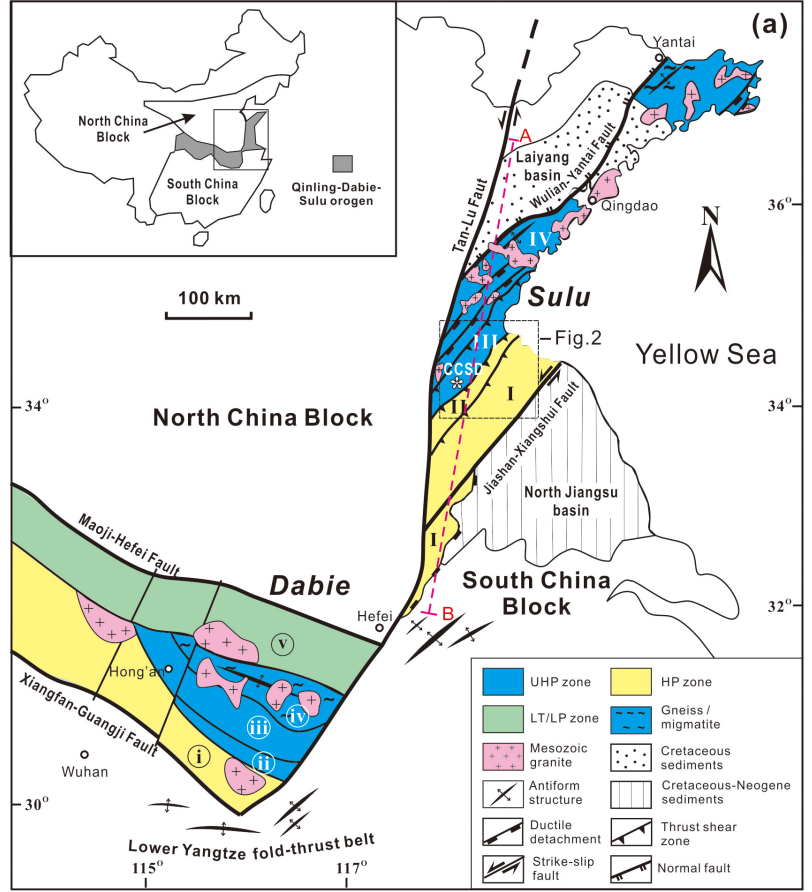

(b)

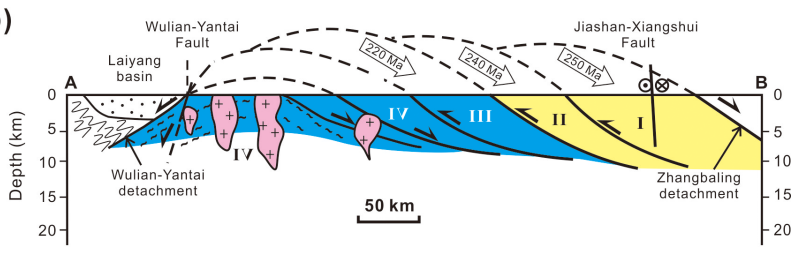

Figure 2. (a) Simplified geological map of the Dabie-Sulu orogenic belt and (b) cross section of the Sulu Terrane (modified after Xu et al., 2009b). The Sulu Terrane consists of four imbricate tectonic slices with different temperature $(T)$ and pressure $(P)$ conditions: I, southern low-T/high pressure (HP) glaucophane zone; II, central mid-T/HP kyanite zone; III, northern midT/ultrahigh-pressure (UHP) supracrustal zone; IV, northern highT/UHP granitic zone. The Dabie Mountains consists of five zones from south to north: i, Susong low-T/HP blueschist facies zone; ii, south Dabie low-T/UHP zone; iii, central Dabie mid-T/UHP zone; iv, north Dabie high-T/UHP zone; v, Beihuaiyang low-T/low$\mathrm{P}$ greenschist facies zone. Star denotes the drilling site of the CCSDMH. Open arrows indicate top-to-the-northwest shearing related to exhumation of the Sulu Terrane, with the starting age of exhumation for different zones.

drilling site of the CCSD-MH is located in the northern UHP supracrustal zone in the Sulu Terrane, where eclogites and garnet peridotites appear as lenses, pods, or layers within coesite-bearing gneisses, quartzite, mica schists, and amphibolites. The northern UHP granitic zone is dominated by granitic gneisses and has been strongly modified by Cretaceous granitic plutons. Exhumation of the HP and UHP slices in the Triassic produced top-to-the-northwest (NW) ductile shear zones in the Sulu Terrane (Fig. 2b). Despite the post-collisional crustal extension and granitic intrusion, 

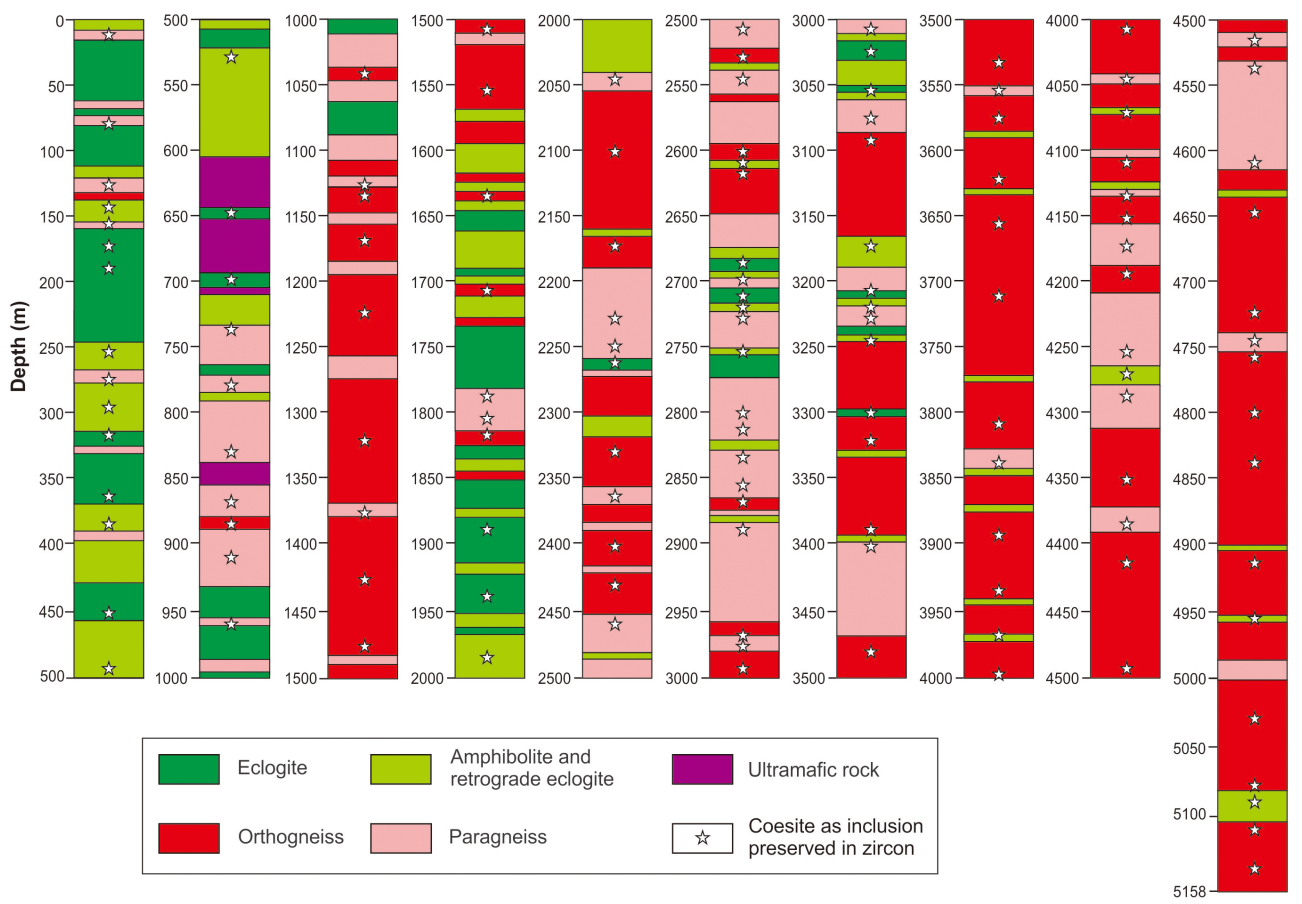

Figure 3. Simplified lithological profile of the CCSD-MH in Donghai County (Liu et al., 2007).

the structural relationship between the HP and UHP slices is well preserved in the Sulu Terrane. Therefore, the CCSD$\mathrm{MH}$ provides us a natural laboratory to investigate physical and chemical properties and geodynamic processes in a continental collision zone.

The objectives of the CCSD project were as follows: (1) to obtain multi-parameter profiles of a $5158 \mathrm{~m}$ deep borehole in the Sulu Terrane, (2) to reconstruct the composition and structure of a deep continental orogenic root, (3) to reveal subduction and exhumation processes of UHP metamorphic terranes, (4) to search deep life in the borehole and constrain fluid-rock interaction, and (5) to establish a long-term observation station using the CCSD-MH.

\subsection{Outstanding progress of the CCSD project}

The CCSD project has produced enormous amounts of data as well as technical innovation in drilling and core recovery. Combined with downhole logging, geophysical experiments, field survey, and laboratory measurements, fresh core samples from the CCSD project provide a valuable resource to study the structure, composition, deformation, physical properties, and material cycling in a continental subduction zone. These results made the Sulu Terrane a classic example to other continental collision zones such as the Himalayas and the Caledonides. In addition, a long-term observation station was set up in the CCSD-MH with continuous downhole monitoring on seismicity, fluid activity, stress, and temperature.

The main progress of the CCSD project is summarized below.
1. Multi-parameter profiles of the $5158 \mathrm{~m}$ deep CCSD$M H$. A full range of physical and chemical measurements of core samples, as well as downhole logging, cuttings, and fluid measurements were carried out for the $5158 \mathrm{~m}$ deep CCSD-MH. About 60 precise and oriented profiles of the CCSD-MH were established, including petrology (Fig. 3), structure (Fig. 4), geochemistry, petrophysics, wellbore breakout, mineralization, fluids, geochronology, oxygen isotopes, heat production elements, downhole logging, and geophysical experiments. These multi-parameter profiles provide a new window into the deep root of a continental collision belt and set up the correlations between chemical and physical properties of UHP rocks.

2. Evidence of deep subduction of huge amount of supracrustal materials. Coesite inclusions in zircon are widely found in eclogites, paragneiss, orthogneiss, schists, kyanite quartzite, and marbles from the surface to $5158 \mathrm{~m}$ depth in the CCSD-MH (Fig. 3) (Liu et al., 2007). Combined with the spatial distribution of UHP rocks in the Dabie-Sulu orogenic belt, huge amounts of supracrustal materials of the South China Block have been subducted to depths of $>100 \mathrm{~km}$ and experienced in situ UHP metamorphism.

3. Timing of subduction, exhumation, and uplift of the Sulu Terrane. The timing of subduction, exhumation, and uplift, as well as the protolith ages of the core samples from the CCSD-MH and pre-pilot boreholes, 


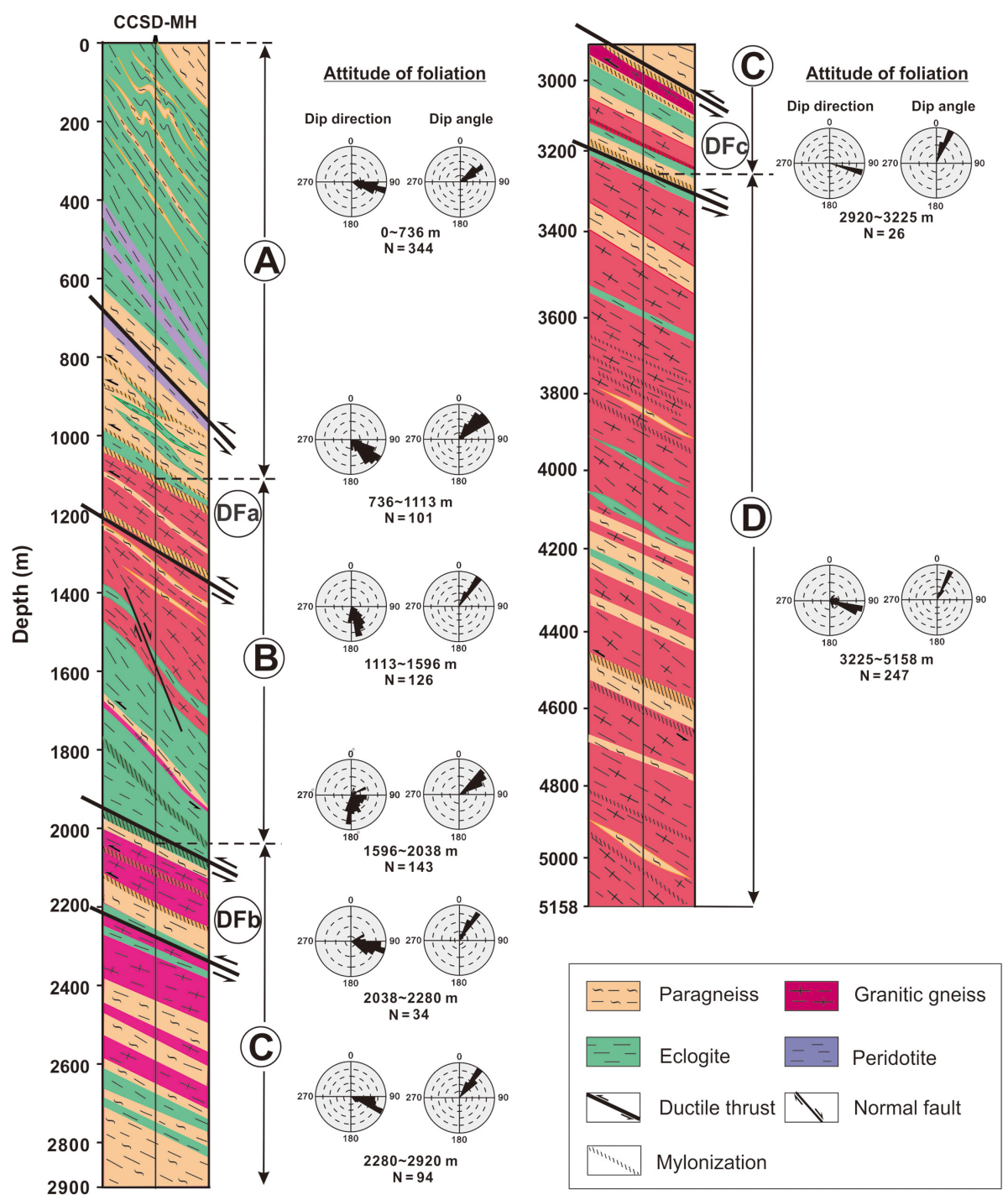

Figure 4. Simplified structural profile of the CCSD-MH in Donghai County (Xu et al., 2009b). The three southeast (SE)-dipping ductile shear zones $\mathrm{DFa}, \mathrm{DFb}$, and $\mathrm{DFc}$ can be traced to the surface according to seismic reflection profiles.

were determined by integrated studies of petrology and geochronology. Zircon U-Pb dating by the SHRIMP and laser ablation inductively coupled plasma mass spectrometry (LA-ICP-MS) indicate an inherited magmatic core of 790-680 Ma, eclogite facies prograde metamorphism at 246-244 Ma, UHP metamorphism at 235-225 Ma, HP eclogite facies recrystallization at 225-215 Ma, and amphibolite facies retrogression at 215-205 Ma (Liu et al., 2001, 2004a, b, 2007; Liu and Liou, 2011; Zhang et al., 2009). In addition, ${ }^{40} \mathrm{Ar} /{ }^{39} \mathrm{Ar}$ cooling ages of biotite from ductile shear zones in the CCSD-MH vary from 218 to $202 \mathrm{Ma}$, suggesting the activation of shear zones during exhumation of UHP metamorphic rocks (Xu et al., 2009b). Apatite fission track analysis indicates an average uplift rate of $\sim 35 \mathrm{~m} \mathrm{Ma}^{-1}$ during 89-30 Ma (Liu et al., 2009).
4. Origin of seismic reflections and crustal structure of the Sulu Terrane. The origin of seismic reflections in the Sulu Terrane was constrained by comparing the lithological/structural profiles (Figs. 3-4), seismic properties of UHP rocks (Kern et al., 2002; Wang et al., 2005a) with the velocity profile of the CCSD-MH, and the seismic reflection profile across the drilling site (Yang, 2009) (Fig. 5) (Xu et al., 2009a). Strong reflections occur at the lithological interfaces between eclogites and country rocks (i.e., paragneiss, granitic gneiss, amphibolite), as well as between eclogite and retrograde eclogite, between eclogite and serpentinized peridotite. Ductile shear zones are extremely reflective. The HP and UHP slices in the Sulu Terrane occur as an eroded rootless dome structure and have been thrust along a se- 
ries of shear zone over a UHP-free middle-lower crust (Figs. 2b and 6) (Wang et al., 2005b; Xu et al., 2009b).

5. New tectonic model of the Sulu Terrane. Crustal structure and pressure-temperature-time-deformation paths of the core samples and outcrop rocks indicate a dome-shaped nappe structure and syn-collisional exhumation of the HP and UHP slices in the Sulu Terrane (Fig. 6) (Xu et al., 2009b). The upper crust of the South China Block was subducted northward to a depth of $\sim 30 \mathrm{~km}$ before $253 \mathrm{Ma}$, and then uplifted to the shallow depth at 250-210 Ma (southern low-T/HP glaucophane zone). The supracrustal rocks continued subduction to $\sim 60 \mathrm{~km}$ and began exhumation at $\sim 240 \mathrm{Ma}$ (central mid-T/HP kyanite zone). At 240-225 Ma, the supracrustal rocks have been subducted to at least $100 \mathrm{~km}$ and experienced UHP metamorphism, and exhumed to $\sim 30 \mathrm{~km}$ at 215 $205 \mathrm{Ma}$. Hence, the UHP rocks experienced fast exhumation $\left(\sim 5 \mathrm{~km} \mathrm{Ma}^{-1}\right)$ at $225-205 \mathrm{Ma}$ at mantle depths, slow uplift $\left(0.96 \mathrm{~km} \mathrm{Ma}^{-1}\right)$ due to Cretaceous granite intrusion and tectonic extension, and unroofing $\left(\sim 35 \mathrm{~m} \mathrm{Ma}^{-1}\right)$ at $89-30 \mathrm{Ma}$.

6. Significant ${ }^{18} \mathrm{O}$ depletion and limited fluid activity in the Sulu Terrane. An O isotope profile of the CCSDMH reveals ${ }^{18} \mathrm{O}$ depletion as deep as $3300 \mathrm{~m}$ and $\mathrm{O}$ isotope heterogeneity between the different and same lithologies on scales of 20 to $50 \mathrm{~cm}$, which are consistent with observations of outcrop rocks and demonstrate limited fluid activity during continental subduction and UHP metamorphism (Zheng et al., 2009). Retrograde fluids came from decomposition of hydrous minerals and the exsolution of structural hydroxyl in nominally anhydrous minerals such as omphacite and garnet. The lithological contacts between eclogites and gneisses are the most favorable place for fluid activity.

7. Bacteria and archaea discovered in the CCSD-MH. About 20 species of bacteria and 4-5 species of archaea were identified from eclogites, amphibolites, and gneisses of the CCSD-MH by DNA analysis. Microbes show a great diversity including metal reducers, methanogens, and methanotrophs, but the diversity decreases with depth. The deepest bacteria occur at $4406.49 \mathrm{~m}$, which gives the bottom boundary for life under extreme conditions in a deep borehole (Fig. 7) (Wang et al., 2006).

\section{The Continental Environmental Scientific Drilling Program of China}

In the late 1990s, Zhisheng An and his group at the Institute of Earth Environment, the Chinese Academy of Sciences proposed to carry out environmental scientific drilling

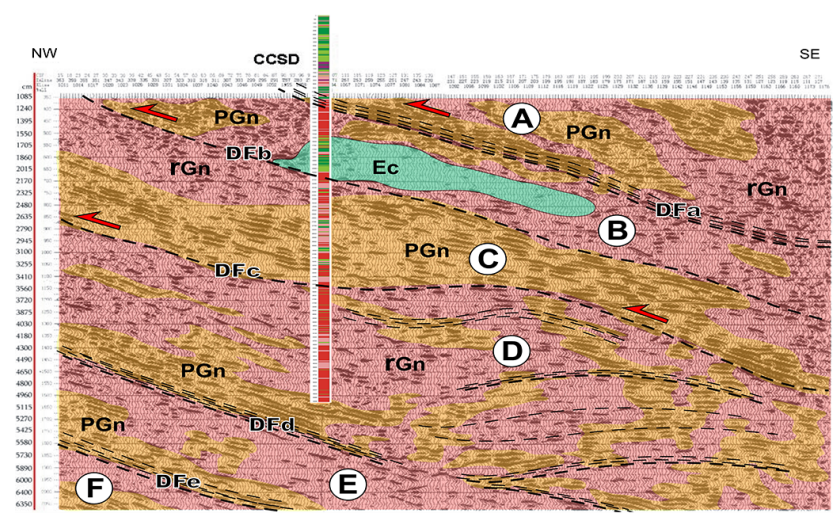

Figure 5. Interpretation of seismic reflection profile across the CCSD-MH (Xu et al., 2009a). A, B, C, D, E and F represent slices of UHP rocks. Ductile shear zones (DFa, DFb, DFc, DFd, and DFe) are recognized according to lithological/ structural profiles and reflectivity. Ec: eclogite; PGn: paragneiss; rGn: granitic gneiss.

in China. The Continental Environmental Scientific Drilling (CESD) Program of China started in 2001 under joint support from the Ministry of Science and Technology, Chinese Academy of Sciences, National Natural Science Foundation of China. This program aims to obtain high-quality geological and biological core records in different environments in China. The core samples will allow scientists to investigate the evolution of Asian monsoon and inland aridification and its relations with regional tectonics and global climate change, and to predict the climate trend in the future. Zhisheng An is the PI of the CESD Program.

The first borehole of the CESD Program was drilled in 2001 in the Heqing Basin in Yunnan Province, to obtain lacustrine deposits for glacial-interglacial Indian summer monsoon dynamics. In 2003 and 2004, $2000 \mathrm{~m}$ core samples in total (including two deep boreholes: $751.98 \mathrm{~m}$ deep Ls1 and $1050.60 \mathrm{~m}$ deep Ls2) were retrieved from Lop Nor, a former salt lake in the Tarim Basin. In 2005, Lake Qinghai Drilling Project was co-funded by the ICDP, Chinese Academy of Sciences and the Ministry of Science and Technology, to investigate the correlation between Asian monsoon and inland aridification during uplift of the Tibetan Plateau.

In addition, late Cenozoic eolian loess-red clay sequences on the Chinese Loess Plateau contain abundant paleoclimatic and paleoenvironmental information, which have been regarded as indicators of paleomonsoon changes and inland Asia desertification. In 2006, two boreholes (555.7 m deep ZL1 and $308.5 \mathrm{~m}$ deep ZL2) were obtained at Zhuanglang County in the western Chinese Loess Plateau and mainly consist of red clay sediments. Since then, a series of drilling projects on loess and lacustrine deposits have been carried out in the Chinese Loess Plateau (e.g., Luochuan, Jingbian) and Xinjiang (e.g., Ili Basin, Junggar Basin). So far the CESD Program has obtained over $10000 \mathrm{~m}$ core samples 
(a)

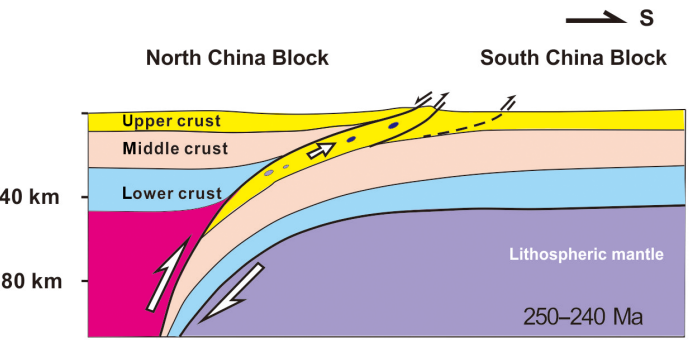

(b)

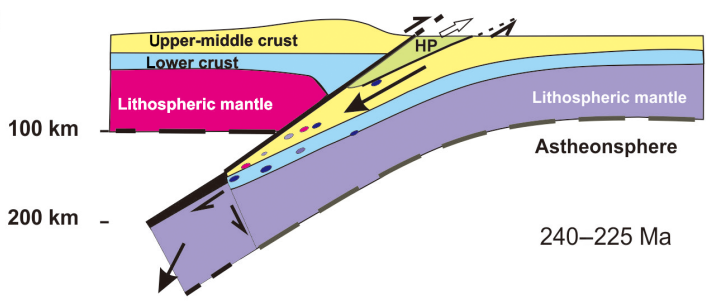

(c)

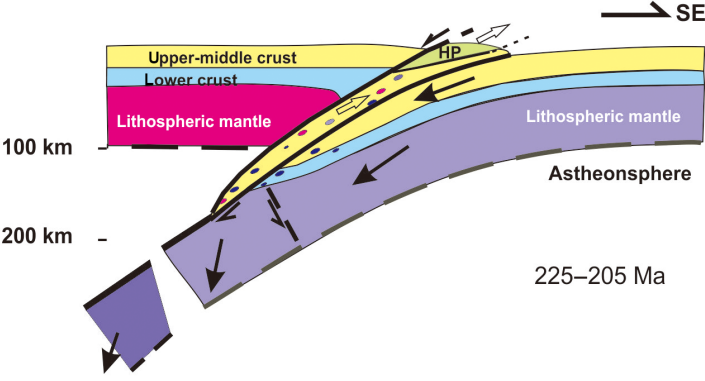

(d)

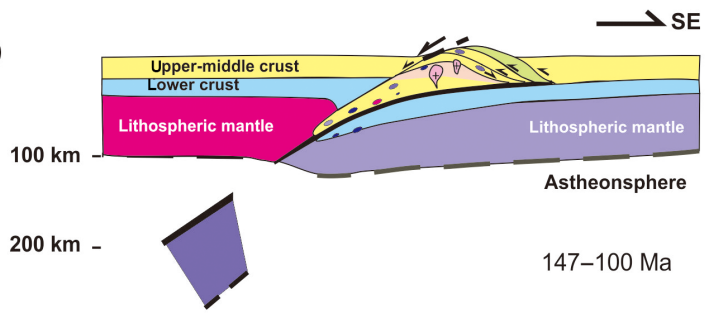

Figure 6. Subduction and exhumation history of the Sulu Terrane (modified after Xu et al., 2009b).

from the Tarim Basin and the Ili Basin in the western arid area, Lake Qinghai and the Loess Plateau in semiarid area, the Heqing Basin in the Indian monsoon area, and the Jianghan Plain in the eastern monsoon area. Great advances have been made in recent years. Here we briefly summarize the results of the Heqing Basin and Lake Qinghai drilling projects.

\subsection{Heqing Basin Drilling Project: glacial-interglacial Indian summer monsoon dynamics}

The modern Indian summer monsoon (ISM) is characterized by exceptionally strong interhemispheric transport, indicating the importance of both Northern and Southern hemispheres processes driving monsoon variability. The first bore-

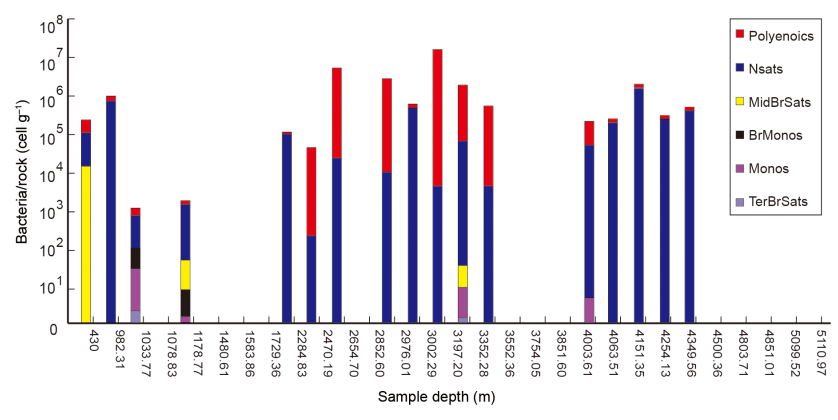

Figure 7. Bacteria and Archaea species from core samples of the CCSD-MH.

hole of the CESD penetrated $666 \mathrm{~m}$ sedimentary sequence in the Heqing paleolake in the southeastern margin of the Tibetan Plateau in 2002. It is so far the longest high-resolution continental record for the ISM evolution.

High-resolution continental record from the Heqing Basin demonstrates the importance of interhemispheric forcing in driving ISM variability at the glacial-interglacial timescale. Interglacial ISM maxima are dominated by an enhanced Indian low associated with global ice volume minima. In contrast, the glacial ISM reaches a minimum, and actually begins to increase, before global ice volume reaches its maximum (Fig. 8). An et al. (2011) indicated that the changing ISM was driven by the relative dominance of the northern low-pressure and southern high-pressure systems during the Pleistocene; both are indispensable for understanding monsoon dynamics. They attribute this early strengthening to an increased cross-equatorial pressure gradient derived from Southern Hemisphere high-latitude cooling. This mechanism explains much of the non-orbital scale variance in the Pleistocene ISM record. The new insight into the ISM on the geological timescale is important for our understanding of global climate evolution in the past. It also provides background information for present and future monsoon changes under global warming (An et al., 2006).

\subsection{Lake Qinghai Drilling Project: interplay between the Westerlies and Asian monsoon}

As the second ICDP project in China, Lake Qinghai Drilling Project was conducted in 2005. A total of $323.23 \mathrm{~m}$ cores were acquired with GLAD800 drilling system by US Lake Drilling Company (DOSECC) at different sub-basins in Lake Qinghai. In addition, two onshore sites were drilled successfully at Erlangjian $(1108.9 \mathrm{~m}$ with core recovery $>90 \%)$ and Yilangjian $(628.5 \mathrm{~m})$ on the southeastern shore of the lake using Chinese equipment (An et al., 2006).

Lake Qinghai is located in the northeastern margin of the Tibetan Plateau. It is extremely sensitive to climate changes because it lies in a critical transitional zone between the humid climate region controlled by the East Asian monsoon and the dry inland region affected by westerly winds. High- 


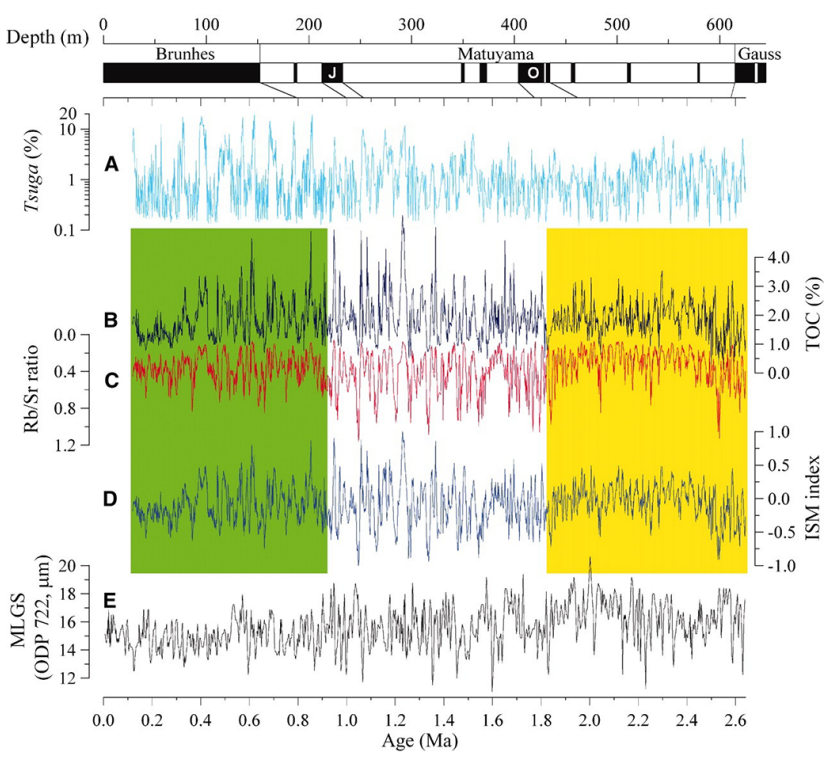

Figure 8. Proxy ISM records since 2.60 Ma from the Heqing Basin, southwestern China (An et al., 2011).

resolution magnetostratigraphy of Yilangjian core samples provides a chronological record back to $\sim 5.1 \mathrm{Ma}$ (Fig. 9). Analysis of lithofacies and depositional environments reveal that the change from eolian to lacustrine facies occurred $\sim 4.63 \mathrm{Ma}$, corresponding to a shift from an arid/semi-arid to a more humid climate, which resulted in the origin of Lake Qinghai (Fu et al., 2013). Changes in sediment lithology and mean grain size indicate that the lake level fluctuated considerably, superimposed on a long-term trend from higher to lower levels in response to East Asian Monsoon variations. This archive provides important information on regional and global environmental change, because so far records from northern China are mainly based on analysis of loess.

The longest core in the Lake Qinghai was obtained in the depositional center of the southwestern sub-basin. The results, constrained by high-resolution AMS ${ }^{14} \mathrm{C}$ dating (An et al., 2012), show the variability of both the Westerlies and the Asian summer monsoon (ASM) since $32 \mathrm{ka}$. These records document the anti-phase relationship of the Westerlies and the ASM on both glacial-interglacial and glacial millennial timescales (Fig. 9). During the last glaciation, the influence of the Westerlies dominated. Prominent dust-rich intervals, correlated with Heinrich events, reflect intensified Westerlies linked to northern high-latitude climate. During the Holocene, the dominant ASM circulation, punctuated by weak events, indicates linkages of the ASM to orbital forcing, North Atlantic abrupt events, and perhaps solar activity changes (An et al., 2012).

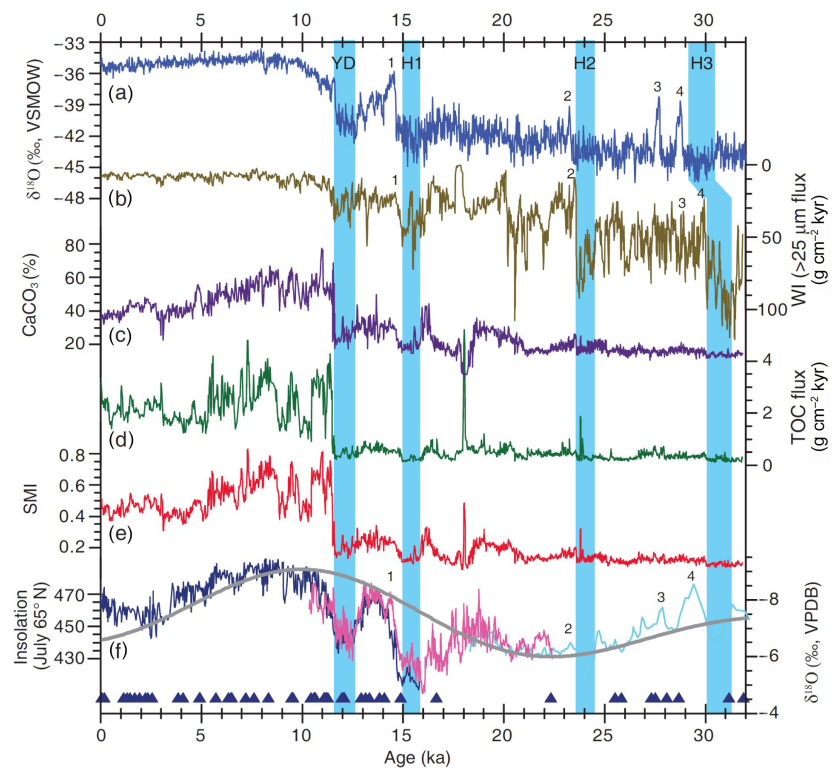

Figure 9. Comparison of Lake Qinghai records with other records during the last $32 \mathrm{kyr}$ (An et al., 2012). (a) NGRIP $\delta^{18} \mathrm{O}^{26}$; (b) North Atlantic ice-rafted hematite stained grains; (c) Lake Qinghai Westerlies climate index (WI, flux of $>25 \mu \mathrm{m}$ fraction); (d) Lake Qinghai Asian summer monsoon index (SMI); (e) $\delta^{18} \mathrm{O}$ record of ostracods from Lake Qinghai; (f) Dongge cave speleothem $\delta^{18} \mathrm{O}^{21}$; (g) atmosphere $\Delta^{14} C^{38}$.

\section{Wenchuan earthquake Fault Scientific Drilling project}

\subsection{Geological background and scientific objectives of the WFSD project}

On 12 May 2008, the $M_{\mathrm{w}} 7.9$ Wenchuan earthquake happened along the northeast (NE)-striking Longmen Shan thrust belt in the eastern margin of the Tibetan Plateau and caused death of over 69227 people and enormous economic loss. In contrast to extremely low GPS shortening rate in the Longmen Shan thrust belt before the earthquake (Zhang et al., 2004), the Wenchuan earthquake is characterized by $>4 \mathrm{~m}$ coseismic slip with comparable magnitude of reverse and right-slip components. It produced $270 \mathrm{~km}$ long surface rupture along the NE-striking Yingxiu-Beichuan fault, and $80 \mathrm{~km}$ long surface rupture along the Anxian-Guanxian fault simultaneously (Li et al., 2008; Liu-Zeng et al., 2009) (Fig. 10).

In order to better understand the fault mechanism and the physical and chemical characteristics of the eastern margin of the Tibetan Plateau, Chinese scientists carried out the WFSD project just 178 days after the earthquake, as an extremely rapid response to the devastating Wenchuan earthquake. The PI of the WFSD project was Zhqin Xu from Chinese Academy of Geological Sciences. The WFSD project eventually drilled six boreholes along the two main earthquake faults (Fig. 11). The first hole (WFSD-1) started on 6 


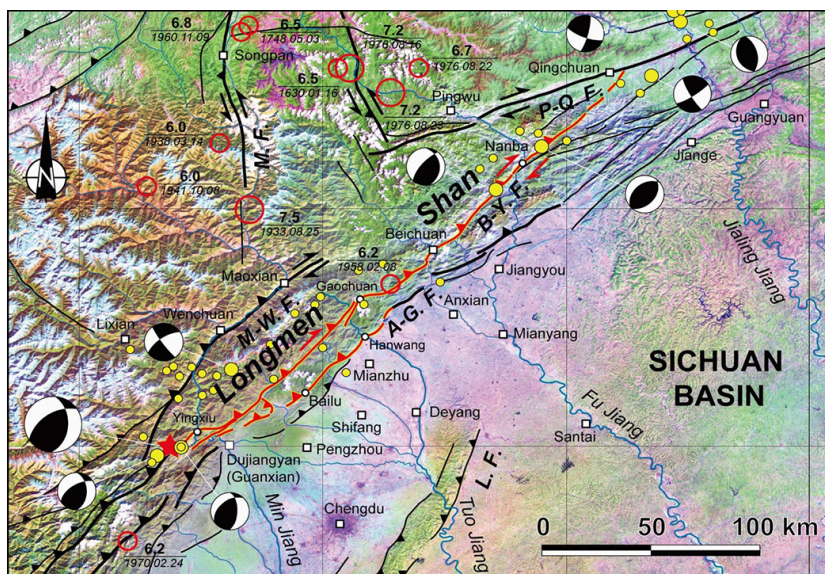

Figure 10. Recent large earthquakes along the eastern margin of the Tibetan Plateau. Red lines show two surface rupture zones caused by the $M_{\mathrm{W}} 7.9$ Wenchuan earthquake.

November 2008 and was completed on 12 July 2009, with a total depth of $1201.15 \mathrm{~m}$.

The scientific objectives of the WFSD project are as follows: (1) to determine the composition, texture, and structure of the fault zones; (2) to reconstruct the physical and chemical properties of the fault zones during the earthquake (frictional coefficient, pore pressure, stress, permeability, seismic velocities, mineral, and chemical compositions), energy budget, and rupture processes; (3) to improve our understanding of the transpressional behavior of this fault zone; (4) to provide key information for the early warning system of future large earthquakes; and (5) to establish a long-term earthquake monitoring station by putting instruments the boreholes.

\subsection{Main progress of the WFSD project}

So far the main results from the WFSD project are as follows:

1. Based on petrological and structural analysis of the core samples from the WFSD project, fault-related rocks (fault gouge, cataclasite, and fault breccia) in the Yingxiu-Beichuan fault and the principle slip zone (PSZ) of the Wenchuan earthquake were determined. Twelve of the 12 fault zones were identified in the entire core profile. At least 10 fault zones, including the Yingxiu-Beichuan fault zone, show a minimum thickness of $\sim 100 \mathrm{~m}$. All major fault zones are characterized by high magnetic susceptibility, low density, and high porosity, with mostly low resistivity, high natural gamma ray, and sound wave velocity (Fig. 12). The high magnetic susceptibility values most likely result from the transformation of magnetic minerals by frictional heating due to the earthquake (Li et al., 2013).

2. The PSZ of the Wenchuan earthquake was found at a depth of $590 \mathrm{~m}$ with $1 \mathrm{~cm}$ wide fresh fault gouge, as

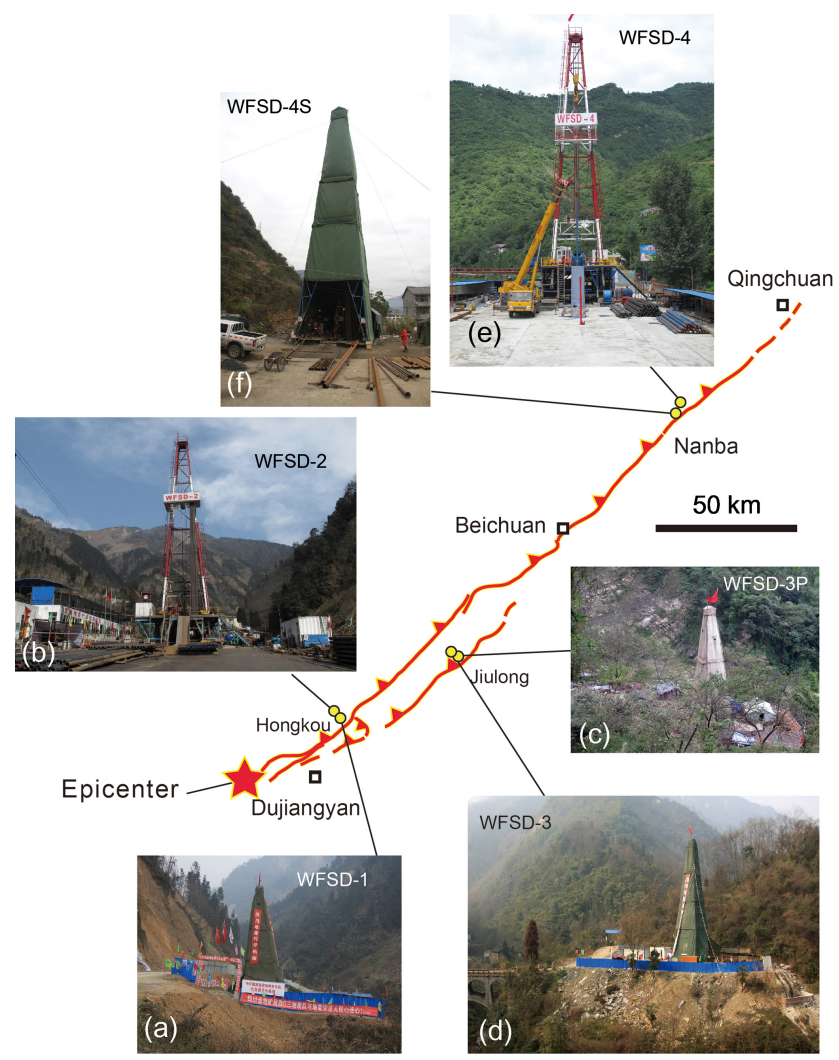

Figure 11. Drilling sites of the Wenchuan Seismic Fault Scientific Drilling along the Longmen Shan thrust belt.

determined by logging data, such as temperature, natural gamma ray, P-wave velocity, and resistivity, combined with the fresh appearance, magnetic susceptibility, and microstructure of the gouge (Fig. 12). The high gamma radiation, porosity, and P-wave velocity, as well as low resistivity, temperature anomalies, and clay mineral anomalies indicate that the Wenchuan earthquake fault zone is located at depth of $585.75-594.5 \mathrm{~m}$, with an average inclination and dip angle of $305^{\circ} \mathrm{N}$ and $71^{\circ}$, respectively ( $\mathrm{Li}$ et al., 2014; $\mathrm{Si}$ et al., 2014). The Wenchuan earthquake slip plane has a dip angle of 71$65^{\circ}$ in the WFSD-1, showing the high-angle thrust feature.

3. The dominant fractures in the core samples of the WFSD- 1 above $600 \mathrm{~m}$ are dipping south with a dip angle of $60^{\circ}$, and change to the NE dipping with a dip angle of $61-83^{\circ}$ below $780 \mathrm{~m}$, which represent the fracture characteristics in the Pengguan Complex and the $\mathrm{Xu}-$ jiahe Formation, respectively. Hence, the hanging wall and footwall of the Yingxiu-Beichuan fault have different stress fields, implying that the Pengguan Complex is allochthon (Li et al., 2014).

4. Deformation experiments and microstructural observations of core samples from the fault slip zone of the 


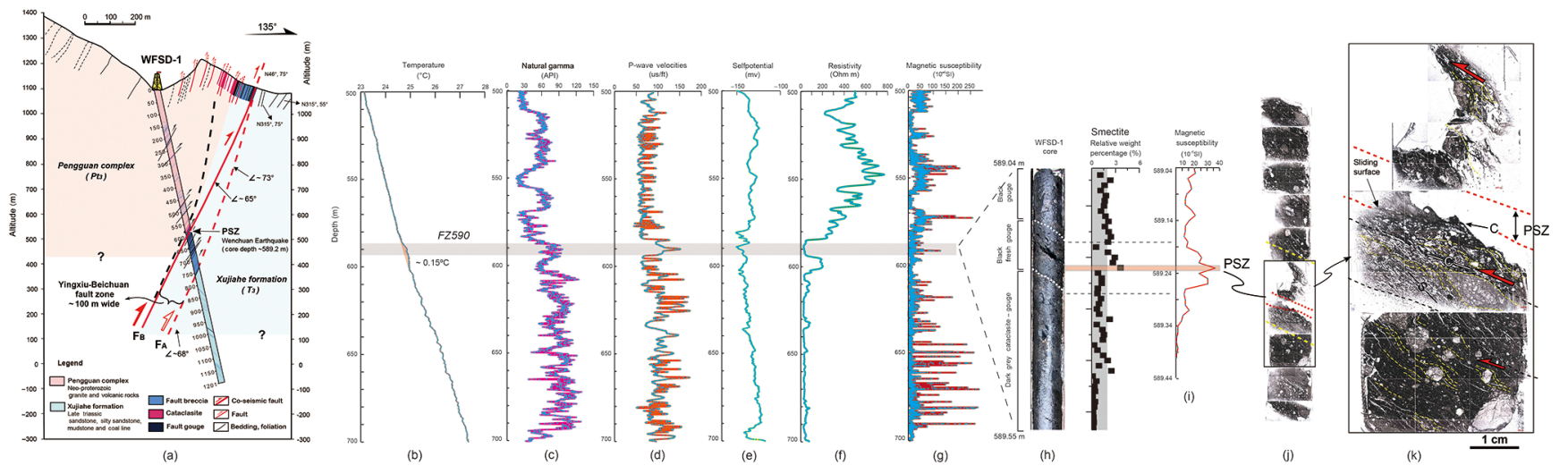

Figure 12. Cross section, logging, and core data of the WFSD-1. The physical anomalies in logging data (b-g) correspond to the fault gauge (h-k) related to the principle slip zone (PSZ) of the Wenchuan earthquake (Li et al., 2013).

(a)

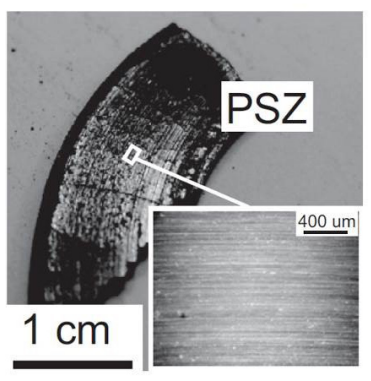

(b)

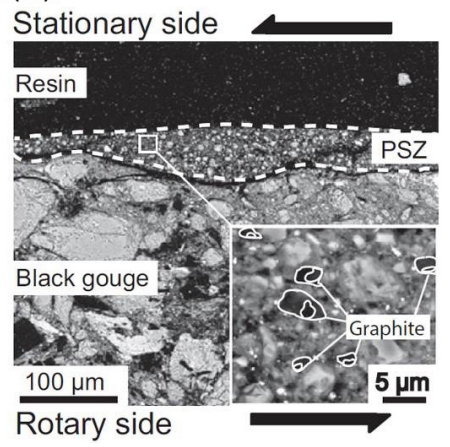

Figure 13. Microstructural characteristics of experimentally deformed black gouges at $15 \mathrm{MPa}$ (Kuo et al., 2014). (a) Photograph of highly reflective surface of the principle slip zone (PSZ) lined by slicken lines and grooves that track the rotary motion of the gouge holder. (b) Backscattered scanning electron microscope (SEM) image of a thin section. The fine-grained PSZ developed adjacent to the stationary side of the gouge holder. Inset backscattered SEM image shows occurrence of small graphite particles by heating of carbonaceous materials (mainly anthracite) during experiments.

WFSD-1 indicate gouge graphitization and dynamic fault weakening (Fig. 13). This suggests that the Longmen Shan fault was extremely weak at borehole depths during the $M_{\mathrm{w}} 7.9$ Wenchuan earthquake, and that enrichment of graphite along localized slip zones could be used as an indicator of transient frictional heating during seismic slip in the upper crust (Kuo et al., 2014).

5. Permeability controls fluid flow in fault zones and is a proxy for rock damage after an earthquake. The tidal response of water level in the WFSD-1 was used to track permeability variations for 18 months in the damage zone of the $M_{\mathrm{w}} 7.9$ Wenchuan earthquake (Fig. 14). The unusually high hydraulic diffusivity of $2.4 \times 10^{-2} \mathrm{~m}^{2} \mathrm{~s}^{-1}$ implies a major role for water circu-
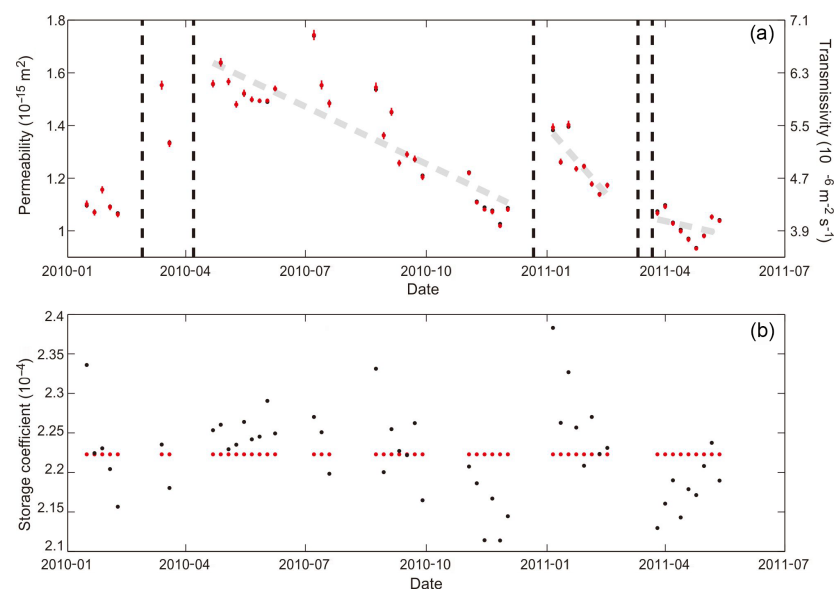

Figure 14. Hydrogeologic properties of the well-aquifer system over time for the WFSD-1 (Xue et al., 2013). (a) Permeability and transmissivity; (b) storage coefficient. Values were inverted from the phase and amplitude of each 29.6-day segment based on the analytical model. Segments that overlap the remote earthquakes (vertical dashed lines) were not inverted. The black dots denote an unconstrained inversion; the red dots are the results of inversion with the storage coefficient fixed to a single value. The best-fit linear trends between each set of permeability data are shown as light gray dashed lines.

lation in the fault zone. For most of the observation period, permeability of the rocks decreased rapidly as the fault healed. The trend was interrupted by abrupt permeability increase due to shaking from remote earthquakes. The continuous permeability measurements reveal a process of punctuated recovery as healing and damage interact in the aftermath of a large earthquake (Xue et al., 2013). 


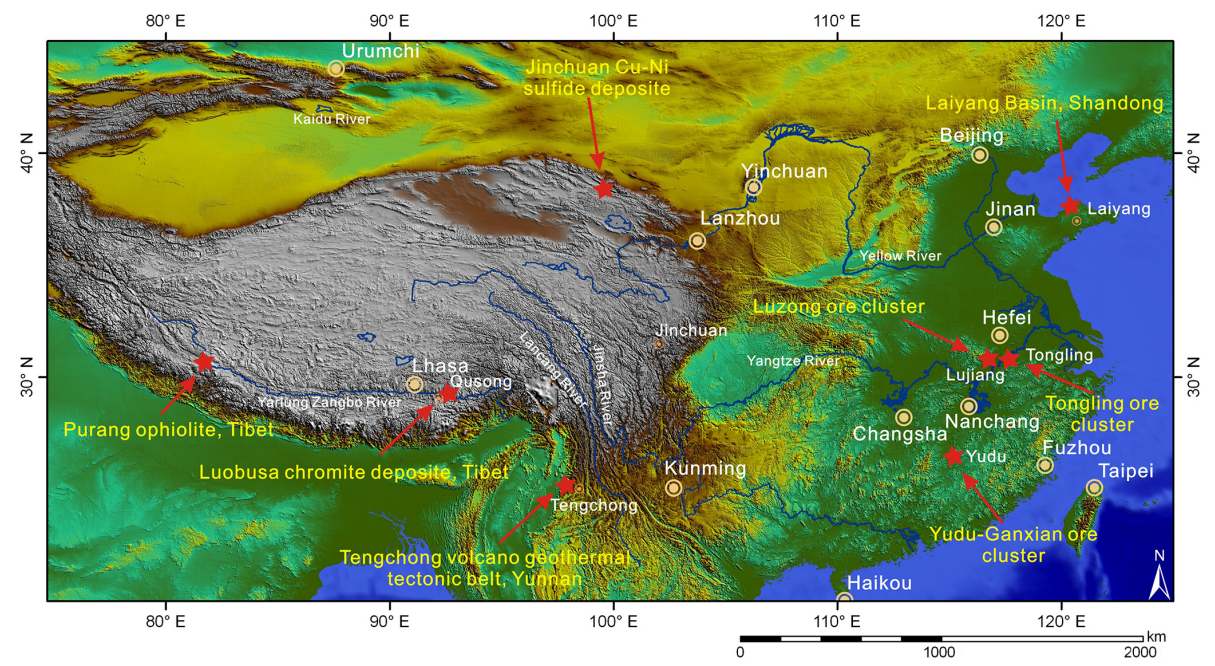

Figure 15. Location of boreholes of Program of Selected Continental Scientific Drilling and Experiments.

\section{Program of Selected Continental Scientific Drilling and Experiments}

\subsection{Scientific objectives}

The SinoProbe Program is the Chinese government-funded Earth science program with the overall aim of exploring the composition, structure, and evolution of the continental lithosphere beneath China and the processes causing geohazards and natural resources (Dong et al., 2013). As one part of the SinoProbe Program, the Program of Selected Continental Scientific Drilling and Experiments (SCSDE) consisted of seven drilling projects in critical tectonic and mineral resource regions from 2008 to 2012. It includes the Jinchuan $\mathrm{Cu}-\mathrm{Ni}$ sulfide deposits in Gansu Province, the Luobusa chromitite deposits in Tibet, the Tengchong volcanothermal tectonic zone in Yunnan Province, the boundary of the North China and South China blocks in the Laiyang Basin of Shandong Province, the Yudu-Ganxian polymetallic deposits in South China, the Tongling polymetallic deposit, and the Luzhong volcanic basin and mineral deposit district in Anhui Province (Fig. 15). The PI of the SCSDE Program is Jingsui Yang from Institute of Geology, Chinese Academy of Geological Sciences.

\subsection{Progress of the Luobusa Scientific Drilling Project}

Ophiolites along the $2000 \mathrm{~km}$ long Yarlung Zangbo suture zone in the Tibetan Plateau mark the collision boundary between the Indian and Eurasian plates. These ophiolites mainly consist of harzburgites and dunites, with minor gabbro dikes and basalts. The Luobusha ophiolite massif contains significant podiform chromitites, which appear as lenticular boudins of high-chrome chromite within dunites (Zhou et al., 1996). This ophiolite massif is believed to have formed initially at an oceanic spreading center at $176 \mathrm{Ma}$ and then been modified by melt-rock reaction in a suprasubduction zone at $126 \mathrm{Ma}$. However, discovery of diamond and some UHP minerals in the Luobusha ophiolite challenges the traditional formation theory of ophiolites (Yang et al., 2007).

The Luobusa Scientific Drilling Project aims to reveal the formation conditions of the deep mantle minerals, the metallogenic mechanism and prospecting criteria of ophiolitetype chromite deposit. The first borehole LBSD-ZK1 ended at a depth of $1478.8 \mathrm{~m}$ with the average core recovery of $94 \%$. The second borehole LBSD-ZK2 has reached a depth of $1600 \mathrm{~m}$ with the average core recovery of $>90 \%$, and the target depth is $2000 \mathrm{~m}$.

The lithological profile of the LBSD-ZK1 indicates that the upper $70 \mathrm{~m}$ is composed of Triassic sandstones, marbles, and chlorite schists, which are in a fault contact with the underlying ultramafic massif. Beneath the fault, there are $1400 \mathrm{~m}$ thick ultramafic rocks. The rest over $100 \mathrm{~m}$ cores are cumulates of dunites and pyroxenites, suggesting that the Luobusha massif is a tectonic slice with a reversed strata sequence (Fig. 16).

Recent studies found abundant diamonds from peridotites and chromitites in ophiolites along the Yarlung Zangbo suture zone, the early Paleozoic Ray-Iz ophiolite in polar Urals (Russia), and in Myanmar (Fig. 17). Chromitites from ophiolites contain crustal minerals such as zircon, and some highly reducing minerals such as carbides, nitrides, and metal alloys (Yang et al., 2014). Some of the minerals are very highpressure phases, implying their origin depth near the top of the mantle transition zone. These new results suggest that crustal materials may be subducted to mantle transition zone and subsequently exhumed during the initiation of new subduction zones. 


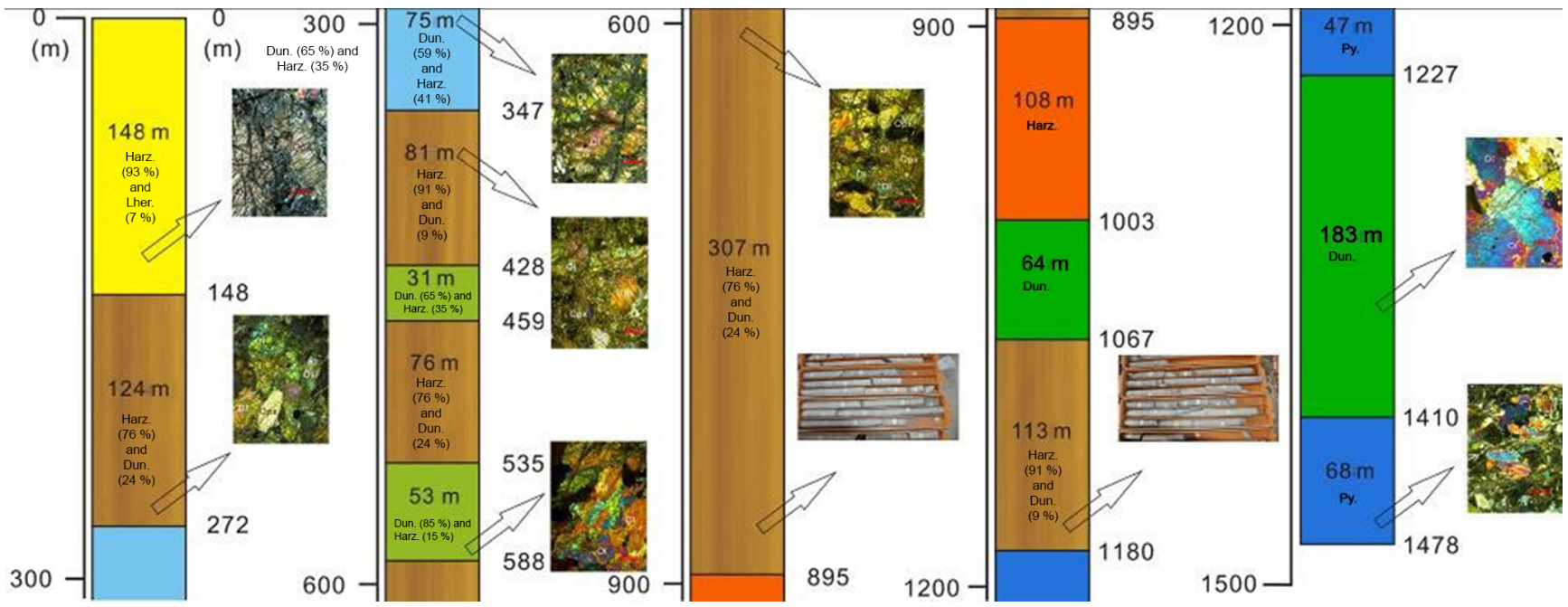

Figure 16. Lithological profiles of the LBSD-ZK1 at the Luobusha ophiolite massif in Tibet.

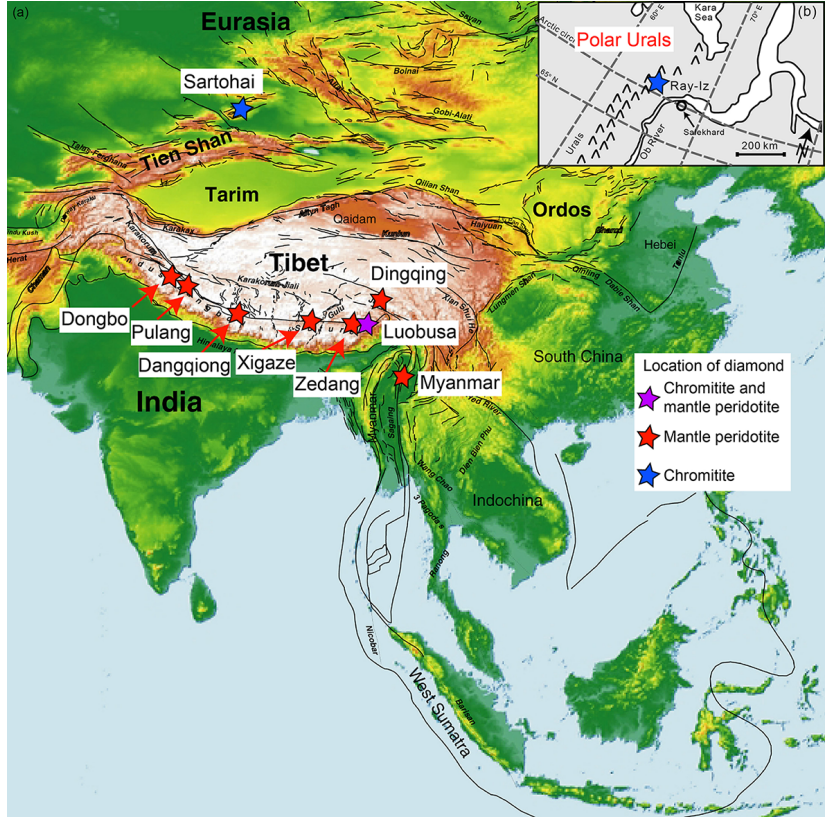

Figure 17. Locations of ophiolite-type diamonds discovered so far. Six locations, including Dongbo, Purang, Dangqiong, Xigaze, Zedang, and Luobusa, and are situated along the Yarlung Zangbo suture zone. One location is at Dingqing in the Bangong-Nujjiang suture, Tibet, one in Myanmar, one in Sartohai in Xinjiang Province (China), and one (see inset map) in the polar Urals, Russia.

\section{Continental Scientific Drilling Project of Cretaceous Songliao Basin}

\subsection{Geological background and scientific objectives}

The Songliao Basin in northeastern China is one of the largest oil- and gas-bearing basins in China. Above a pre-

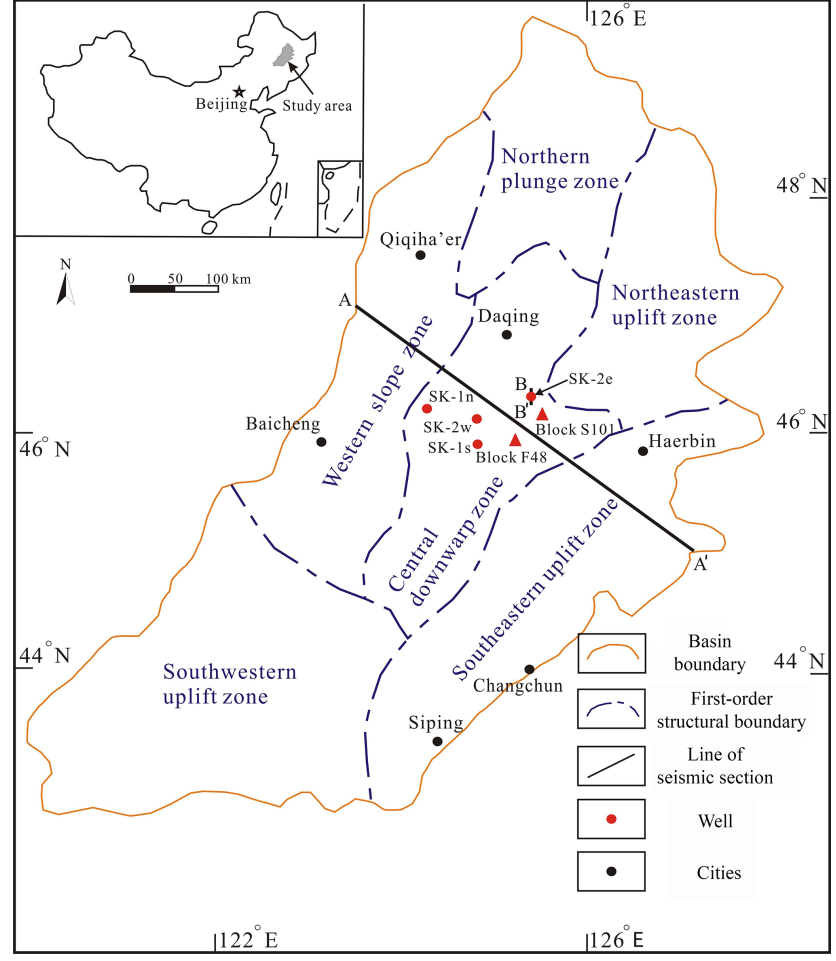

Figure 18. Tectonic scheme of the Songliao Basin with the location of SK-1 and SK-2 boreholes. The tectonic scheme is according to Zhou and Littke (1999). SK-1s and SK-1n are the north and south hole sites of SK-1, respectively, while SK-2e and SK-2w are the east and west hole sites of SK-2, respectively. A- $\mathrm{A}^{\prime}$ : the SE-NW cross-seismic profile.

Mesozoic basement, the Songliao Basin was filled predominantly with volcanoclastic, alluvial fan, fluvial, and lacustrine sediments of Late Jurassic, Cretaceous, and Paleogene ages. It can be divided into the six tectonic units: western 


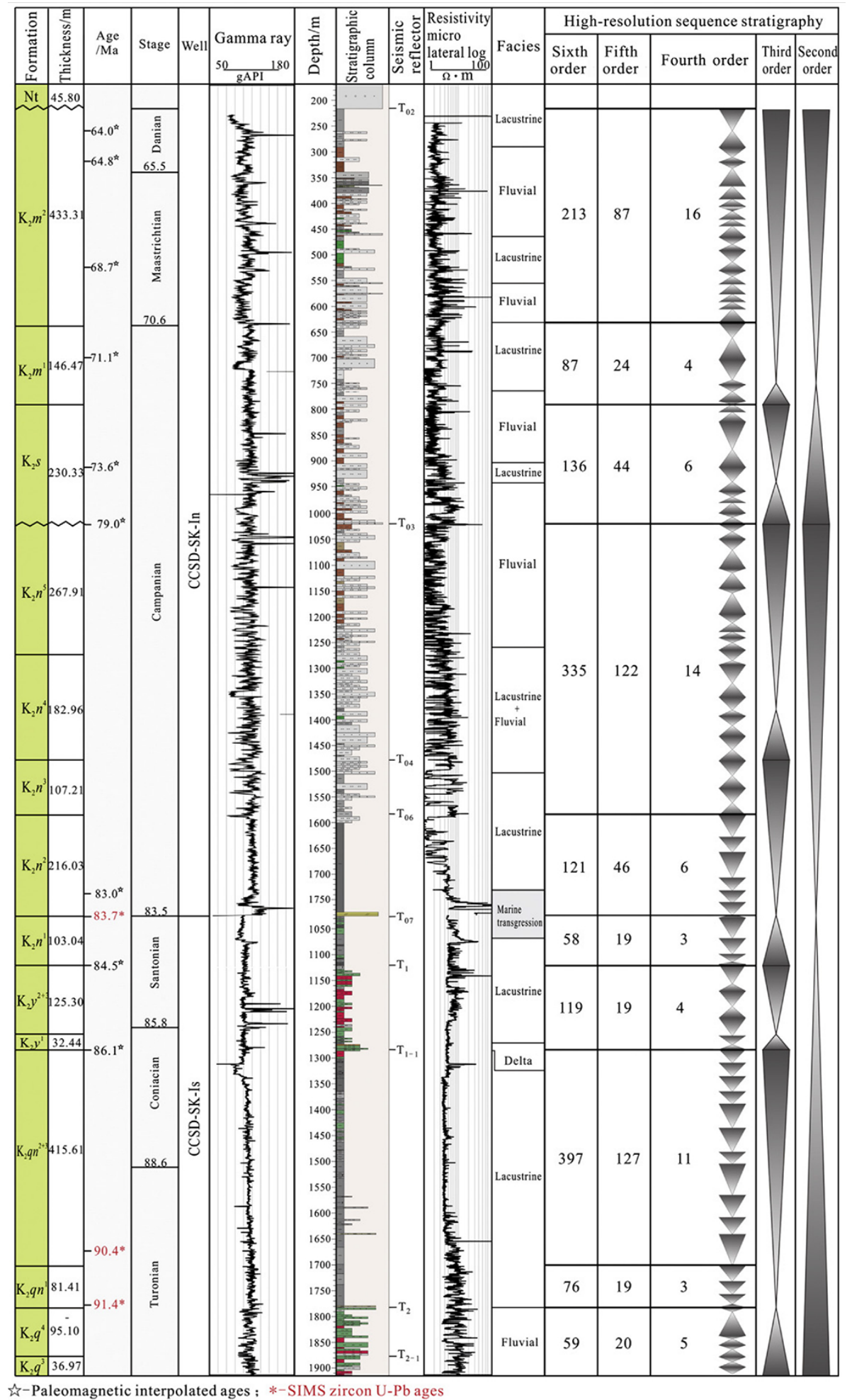

Figure 19. High-resolution sequence stratigraphy of Upper Cretaceous in the Songliao Basin. The figure on the right side of each segment is the number of cycles in each member or formation. Modified from Gao et al. (2009) (Wang et al., 2013b). 


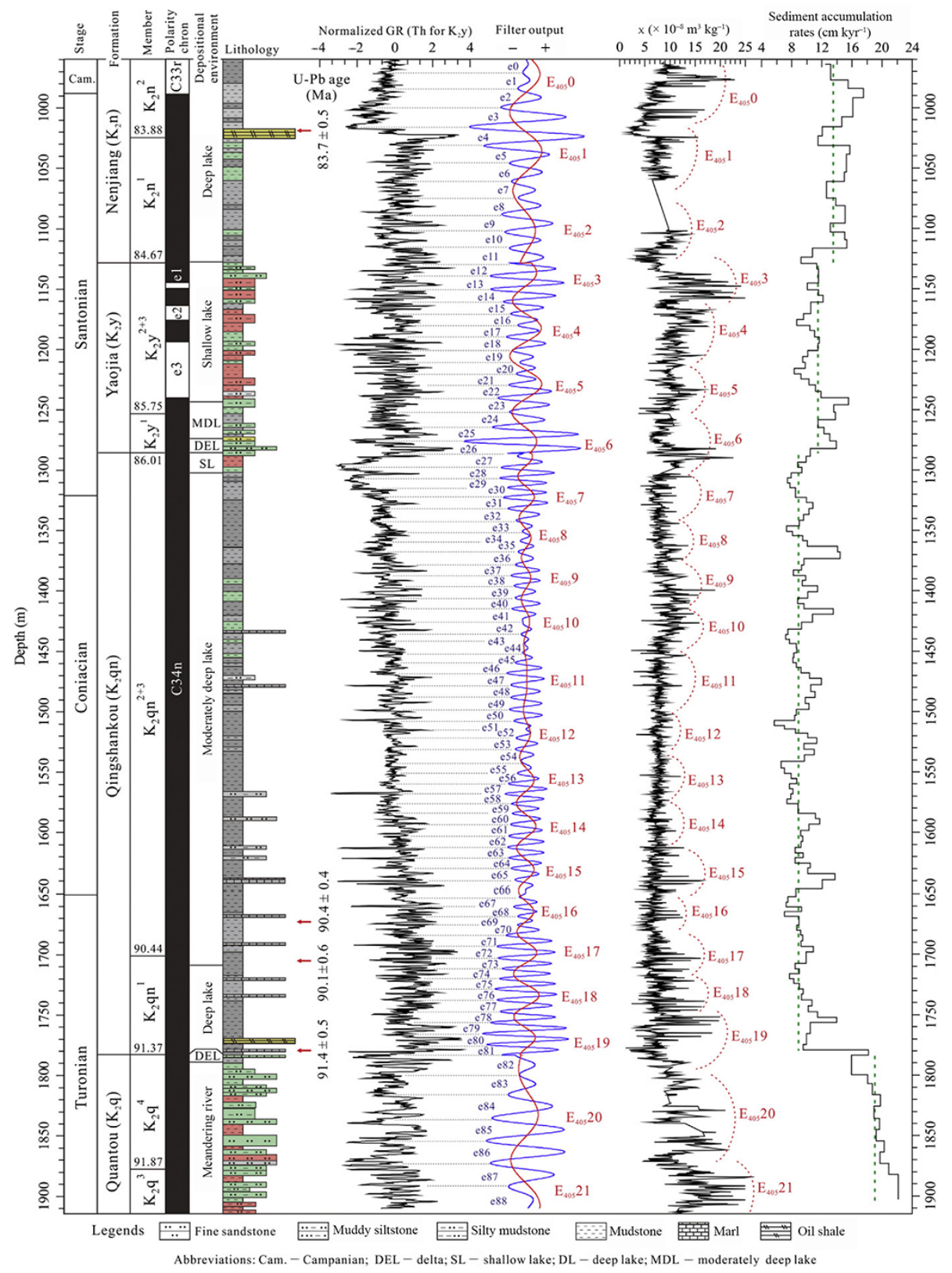

Figure 20. Cyclostratigraphic interpretation and sedimentary accumulation rates of the SK-1 south core in the Songliao Basin (Wang et al., 2013b). The numbers at the member column are the astronomical timescale ages in "Ma" for the strata boundaries. The "e" (blue) and "E" (red) represent $100 \mathrm{kyr}$ short and $405 \mathrm{kyr}$ long eccentricity cycles, respectively.

ramp region, northern plunge region, central depression region, northeastern uplift region, southeastern uplift region, and southwestern uplift region (Fig. 18) (Wang et al., 2013a).

There is an increasing likelihood that our world is moving toward a greenhouse state due to increases in anthropogenic carbon dioxide in the atmosphere (Hay, 2011). This change provides a powerful motivation for understanding the dynamics of Earth's past "greenhouse" climate. Cretaceous is characterized by long-term climate stability with warm equable climates due to a higher atmospheric greenhouse gas content, and punctuated by rapid climate events related to global carbon and hydrological cycle (Bornemann et al., 2008). The Continental Scientific Drilling Project of the Cretaceous Songliao Basin, composed of SK-1 and SK-2 boreholes, was proposed to recover almost full Cretaceous strata in the Songliao Basin in eastern China (Feng et al., 2013). The PI of this project is Chengshan Wang from China University of Geosciences (Beijing). 


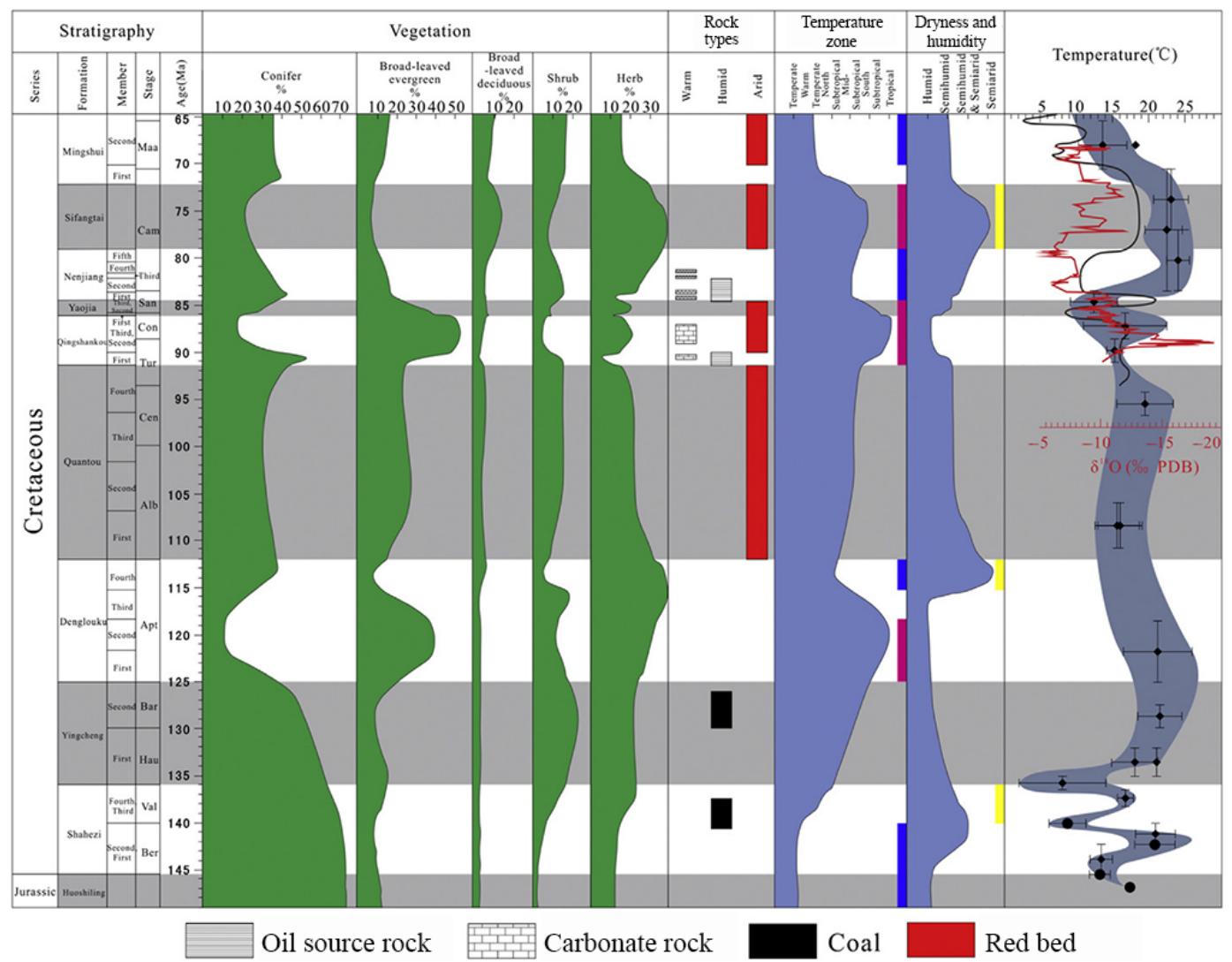

Figure 21. Cretaceous paleoclimate evolution of the Songliao Basin. Spore/pollen relative abundances, paleotemperature zones, and paleohumidity are from Gao et al. (2009). Those of the Far East are from Zakharov et al. (1999). The oxygen isotope data are from Chamberlain et al. (2013). The red bars indicate warming stages, the blue bars indicate cooling stages, and the yellow bars indicate semiarid stages.

\subsection{Preliminary progress of the Songliao Basin Drilling Project}

The newly finished SK-1 borehole has recovered Upper Cretaceous strata in the Songliao Basin, which offered an unprecedented chance to decipher the Cretaceous terrestrial climate change. The core samples reflect many facets of paleoenvironmental and climate changes during the Late Cretaceous in eastern China, which have attracted a wide range of Earth scientists to compare with other areas in the world.

Base-level cycles are driven either by relative sea level or by tectonic changes. In marine basins eustasy alters accommodation space as sea level rises and falls. In intracontinental basins tectonics drive both basin subsidence and depositional cycles. Core samples from the SK-1 indicate that the Songliao Basin was isolated from the ocean except for two brief periods in the late Turonian of the Qingshankou Formation and in the early Campanian in the lower part of the Nenjiang Formation (Xi et al., 2011). Paleoclimate research has shown that astronomical forcing drove global climate change in the Earth's history and may be recorded in both continental and marine sedimentary strata. The orbitally forced cycles are recorded in Cretaceous marine successions around the world, which provide a calibration tool of the Cretaceous timescale. Milankovitch cycles were recently identified in Late Cretaceous terrestrial strata in the Songliao Basin (Wang et al., 2013a).

High-resolution sequence stratigraphy of the Upper Cretaceous section cored in the SK-1 (Fig. 19) was based on centimeter-by-centimeter description integrated with well logs, seismic data, and well-to-well correlation in the Songliao Basin. Upper Cretaceous of the Songliao Basin can be subdivided into sequences of 2 second order, 6 third order, 72 fourth order, 527 fifth order and 1601 sixth order (Gao et al., 2009; Wang et al., 2013b).

Cyclostratigraphic analyses on the Quantou, Qingshankou, Yaojia, and Nenjiang Formations in the SK-1 south well confirmed the excellent preservation of astronomically driven sedimentary cycles, including long and short eccentricity, obliquity, and precession cycles constrained by four high-resolution SIMS U-Pb zircon ages (Fig. 20).

The climate history of the Songliao Basin is based on pollen and spore ratios (Fig. 21) using more than 20000 samples from more than 500 cores. The Cretaceous vegetation landscape of the basin fluctuated between a conifer forest and an herbaceous-broadleaved forest. Climates of the Songliao 
Basin are compared with the marine oxygen isotopic data of Far East (Zakharov et al., 1999) (Fig. 21). The classification of temperature zones is based on the species of spore/pollen spectra that define the tropical, tropical-subtropical, subtropical, tropical-temperate, and temperate, as well as the oxygen isotopic trends of the Songliao Basin. The dryness and humidity are based on species of parent plants of spore/pollen fossils subdivided into xerophyte, mesophyte, hygrophyte, helophyte, and hydrophyte, which correspond to arid, semiarid, semihumid and semiarid, semihumid, and humid, respectively.

Partially based on the successful SK-1 borehole, the ICDP approved the SK-2 drilling proposal in September 2009. The SK-2 borehole is to recover Lower Cretaceous strata with an estimated drilling depth of nearly $7000 \mathrm{~m}$. Hence, the SK1 and SK-2 boreholes can provide continuous sedimentary records of the Cretaceous in the Songliao Basin. The drilling operation of SK-2 started in April 2014, because Chinese engineers developed new drilling equipment for a superdeep borehole of $\sim 10000 \mathrm{~m}$. The SK-2 borehole also adopted "one-well, two-hole" design (Fig. 18). The west hole SK-2w is located in Changyuan of Daqing City and will recover the Quantou-Denglouku Formation. The east hole SK-2e is located in the Xujiaweizi Fault Depression, and will recover the Yingcheng Formation-Huoshiling Formation. The two holes will be interconnected and correlated by the T4 seismic reflection interface. The east and west holes of SK-2 will become the main wells of the proposed deep underground laboratory. The target depth of the east hole SK-2e is $6400 \mathrm{~m}$, which will be the deepest one in the Songliao Basin and in eastern China. More comprehensive understanding of paleoenvironmental and climatic change for the Cretaceous Songliao Basin would be achieved after the accomplishment of the SK-2. Compared with drilling projects in the ocean, loess plateau, and modern lakes, scientific drilling projects in giant paleolakes should be an indispensable part to understand the paleoenvironments and climatic changes from the terrestrial realm.

\section{Conclusions}

Accompanied with growth of the ICDP, each project of the CCSD Program has a struggle history with expected and unexpected difficulties, and recorded the development in science and technology. The increasing international cooperation in the CCSD Program demonstrates that curiosity of scientists has no borders, and the science-driven policy of the ICDP is highly appreciated.

Data availability. Data used for this work can be found in An et al. (2011, 2012), Li et al. (2013), Xu et al. (2009b), and Xue et al. (2013).
Competing interests. The authors declare that they have no conflict of interest.

Acknowledgements. We are grateful to the ICDP, the Ministry of Land Resources of China, the Ministry of Science and Technology of China, and Natural Science Foundation of China for providing continuous support to the CCSD Program. We thank all crews, drilling team members, and lab technicians in the CCSD Program, and thank all scientists for making exciting discoveries from these boreholes. Constructive review of two anonymous reviewers and the editor T. Wiersberg is appreciated.

Edited by: T. Wiersberg

Reviewed by: two anonymous referees

\section{References}

An, Z. S., Wang, P., Shen, J., Zhang, Y., Zhang, P., Wang, S., Li, X., Sun, Q., Song, Y., Ai, L., Zhang, Y., Jiang, S., Liu, X., and Wang, Y.: Geophysical survey on the tectonic and sediment distribution of Qinghai Lake basin, Sci. China, Ser. D Earth Sci., 49, 851861, 2006.

An, Z. S., Clemens, S. C., Shen, J., Qiang, X., Jin, Z., Sun, Y., Prell, W.L., Luo, J., Wang, S., Xu, H., Cai, Y., Zhou, W., Liu, X., Liu, W., Shi, Z., Yan, L., Xiao, X., Chang, H., Wu, F., Ai, L., and Lu, F.: Glacial-interglacial Indian summer monsoon dynamics, Science, 333, 719-723, 2011.

An, Z. S., Colman, S. M., Zhou, W., Li, X., Brown, E., Jull, A. J. T., Cai, Y., Huang, Y., Lu, X., Chang, H., Song, Y., Sun, Y., Xu, H., Liu, W., Jin, Z., Liu, X., Cheng, P., Liu, Y., Ai, L., Li, X., Liu, X., Yan, L., Shi, Z., Wang, X., Wu, F., Qiang, X., Dong, J., $\mathrm{Lu}, \mathrm{F}$., and $\mathrm{Xu}, \mathrm{X}$.: Interplay between the Westerlies and Asian monsoon recorded in Lake Qinghai sediments since $32 \mathrm{ka}$, Sci. Rep., 2, 619, doi:10.1038/srep00619, 2012.

Bornemann, A., Norris, R. D., Friedrich, O., Beckmann, B., Schouten, S., Damste, J. S. S., Vogel, J., Hofmann, P., and Wagner, T.: Isotopic evidence for glaciation during Cretaceous supergreenhouse, Science, 319, 189-192, 2008.

Chamberlain, C. P., Wan, X., Graham, S. A., Carroll, A. R., Doebbert, A. C., Sageman, B. B., Blisniuk, P., Kent-Corson, M. L., Wang, Z., and Wang, C. S.: Stable isotopic evidence for climate and basin evolution of the Late Cretaceous Songliao basin, China, Palaeogeogr. Palaeoclimatol. Palaeoecol., 385, 106-124, 2013.

Cong, B. L.: Ultrahigh-pressure Metamorphic Rocks in the Dabieshan-Sulu Region of China, Science Press, Beijing, 224 pp., 1996.

Dong, S. W., Li, T. D., Lü, Q. T., Gao, R., Yang, J. S., Chen, X. H., Wei, W. B., Zhou, Q., and SinoProbe team: Progress in deep lithospheric exploration of the continental China: A review of the SinoProbe, Tectonophysics, 606, 1-13, 2013.

Feng, Z., Wang, C., Graham, S., Koeberl, C., Dong, H., Huang, Y., and Gao, Y.: Continental Scientific Drilling Project of Cretaceous Songliao Basin: Scientific objectives and drilling technology, Palaeogeogr. Palaeoclimatol. Palaeoecol., 385, 6-16, 2013.

Fu, C. F., An, Z. S., Qing, X. K., Bloemendal, J., Song, Y. G., and Chang, H.: Magnetostratigraphic determination of the age of an- 
cient Lake Qinghai, and record of the East Asian monsoon since 4.63 Ma, Geology, 41, 875-878, 2013.

Gao, Y., Wang, P., Cheng, R., Wang, G., Wan, X., Wu, H., Wang, S., and Liang, W.: Description of Cretaceous sedimentary sequence of the first member of the Qingshankou Formation recovered by CCSD-SK-I s borehole in Songliao Basin: lithostratigraphy, sedimentary facies and cyclic stratigraphy, Earth Sci. Front., 16, 314323, 2009 (in Chinese with English abstract).

Hacker, B. R., Ratschbacher, L., Webb, L., Ireland, T., Walker, D., and Dong, S. W.: U/Pb zircon ages constrain the architecture of the ultrahigh-pressure Qinling-Dabie Orogen, China, Earth Planet. Sci. Lett., 161, 215-230, 1998.

Hay, W.: Can humans force a return to a 'Cretaceous' climate?, Sediment. Geol., 235, 5-26, 2011.

Hermann, J. and Rubatto, D.: Subduction of continental crust to mantle depth: geochemistry of ultrahigh-pressure rocks, Treatise Geochemistry, 4, 309-340, 2014.

Kern, H., Jin, Z. M., Gao, S., Popp, T., and Xu, Z. Q.: Physical properties of ultrahigh-pressure metamorphic rocks from the Sulu terrain, eastern central China: implications for the seismic structure at the Donghai (CCSD) drilling site, Tectonophysics, 354, 315330, 2002.

Kuo, L. W., Li, H., Smith, S., Smith, S. A. F., Di Toro, G., Suppe, J., Song, S., Nielsen, S., Sheu, H. S., and Si, J.: Gouge graphitization and dynamic fault weakening during the $2008 \mathrm{Mw} 7.9$ Wenchuan earthquake, Geology, 42, 47-50, 2014.

Li, H. B., Fu, X. F., Van der Word, J., Si, J. L., Wang, Z. X., Hou, L. W., Qiu, Z. L., Li, N., Wu, F. Y., Xu, Z. Q., and Tapponnier, P.: Co-seisimic surface rupture and dextral-slip oblique thrusting of the Ms 8.0 Wenchuan earthquake, Acta Geological Sinica, 82, 1623-1643, 2008 (in Chinese with English abstract).

Li, H. B., Wang, H., Xu, Z. Q., Si, J., Pei, J., Li, T., Huang, Y., Song, S., Kuo, L., Sun, Z., Chevalier, M. L., and Liu, D.: Characteristics of the fault-related rocks, fault zones and the principal slip zone in the Wenchuan Earthquake Fault Scientific Drilling Project Hole-1 (WFSD-1), Tectonophysics, 584, 23-42, 2013.

Li, H. B., Xu, Z. Q., Niu, Y., Kong, G., Huang, Y., Wang, H., Si, J., Sun, Z., Pei, J., and Gong, Z.: Structural and physical property characterization in the Wenchuan Earthquake Fault Scienti?c Drilling project - hole 1 (WFSD-1), Tectonophysics, 619-620, 86-100, 2014.

Li, S. G., Jagoutz, E., Chen, Y. Z., and Li, Q. L.: Sm-Nd and Rb$\mathrm{Sr}$ isotopic chronology and cooling history of ultrahigh pressure metamorphic rocks and their country rocks at Shuanghe in the Dabie Mountains, Central China, Geochim Cosmochim Acta, 64, 1077-1093, 2000.

Liou, J. G., Ernst, W. G., Zhang, R. Y., Tsujimori, T., and Jahn, J. G.: Ultrahigh-pressure minerals and metamorphic terranes - the view from China, J. Asian Earth Sci., 35, 199-231, 2009.

Liou, J. G., Tsujimori, T., Yang, J. S., Zhang, R. Y., and Ernst, W. G.: Recycling of crustal materials through study of ultrahighpressure minerals in collisional orogens, ophiolites, and mantle xenoliths: A review, J. Asian Earth Sci., 96, 386-420, 2014.

Liu, D. Y., Jian, P., Kröner, A., and Xu, S. T.: Dating of prograde metamorphic events deciphered from episodic zircon growth in rocks of the Dabie-Sulu UHP complex, China, Earth Planet. Sci. Lett., 250, 650-666, 2006.

Liu, F. L. and Liou, J. G.: Zircon as the best mineral for P-T-time history of UHP metamorphism: A review on mineral inclusions and U-Pb SHRIMP ages of zircons from the Dabie-Sulu UHP rocks, J. Asian Earth Sci., 40, 1-39, 2011.

Liu, F. L., Xu, Z. Q., Katayama, I., Yang, J. S., Maruyama, S., and Liou, J. G.: Mineral inclusions in zircons of para- and orthogneiss from pre-pilot drillhole CCSD-PP1, Chinese Continental Scientific Drilling Project, Lithos, 59, 199-215, 2001.

Liu, F. L., Xu, Z. Q., and Xue, H.: Tracing the protolith, UHP metamorphism, and exhumation ages of orthogneiss from the SW Sulu terrane (eastern China): SHRIMP U-Pb dating of mineral inclusion-bearing zircons, Lithos, 78, 411-429, 2004a.

Liu, F. L., Xu, Z. Q., Liou, J. G., and Song, B.: SHRIMP U-Pb ages of ultrahigh-pressure and retrograde metamorphism of gneisses, south-western Sulu terrane, eastern China, J. Metamorphic Geol., 22, 315-326, 2004b.

Liu, F. L., Xu, Z. Q., Liou, J. G., Dong, H. L., and Xue, H. M.: Ultrahigh-pressure mineral assemblages in zircons from the surface to $5158 \mathrm{~m}$ depth in cores of the main drill hole, Chinese Continental Scientific Drilling Project, southwestern Sulu belt, China, Int. Geol. Rev., 49, 454-478, 2007.

Liu, S. S., Weber, U., Glasmacher, U. A., Xu, Z., and Wagner, G. A.: Fission track analysis and thermotectonic history of the main borehole of the Chinese Continental Scientific Drilling project, Tectonophysics, 475, 318-326, 2009.

Liu-Zeng, J., Zhang, Z., Wen, L., Tapponnier, P., Sun, J., Xing, X., Hu, G., Xu, Q., Zeng, L., Ding, L., Ji, C., Hudnut, K. W., and van der Woerd, J.: Co-seismic ruptures of the 12 May 2008, Ms 8.0 Wenchuan earthquake, Sichuan: East-west crustal shortening on oblique, parallel thrusts along the eastern edge of Tibet, Earth Planet. Sci. Lett., 286, 355-370, 2009.

Okay, A. I., Xu, S. T., and Sengor, A. M. C.: Coesite from the Dabie Shan eclogites, central China, Eur. J. Mineral., 1, 595-598, 1989.

Si, J., Li, H., Kuo, L., Pei, J., Song, S., and Wang, H.: Clay mineral anomalies in the Yingxiu-Beichuan fault zone from the WFSD-1 drilling core and its implication for the faulting mechanism during the 2008 Wenchuan earthquake (Mw 7.9), Tectonophysics, 619, 171-178, 2014.

Wang, C. S., Feng, Z., Wu, H., Wang, P., Kong, F., Feng, Z., Ren, Y., Yang, G., Wan, X., Huang, Y., and Zhang, S.: Preliminary Achievement of the Chinese Cretaceous Continental Scientific Drilling Project SK-I, Acta Geologica Sinica, 82, 9-20, 2008 (in Chinese with English abstract).

Wang, C. S., Feng, Z., Zhang, L., Huang, Y., Cao, K., Wang, P., and Zhao, B.: Cretaceous paleogeography and paleoclimate and the setting of SKI borehole sites in Songliao Basin, northeast China, Palaeogeogr. Palaeoclimatol. Palaeoecol, 385, 17-30, 2013a.

Wang, C. S., Scott, R. W., Wan, X., Graham, S. A., Huang, Y. J., Wang, P. J., Wu, H. C., Dean, W. E., and Zhang, L. M.: Late Cretaceous climate changes recorded in Eastern Asian lacustrine deposits and North American Epieric sea strata, Earth Sci. Rev., 126, 275-299, 2013b.

Wang, Q., Ji, S. C., Salisbury, M. H., Pan, M. B., Xia, B., and Xu, Z. $\mathrm{Q} .:$ Pressure dependence and anisotropy of $\mathrm{P}$-wave velocities in ultrahigh-pressure metamorphic rocks from the Dabie-Sulu orogenic belt (China): implications for seismic properties of subducted slabs and origin of mantle reflections, Tectonophysics, 398, 67-99, 2005a.

Wang, Q., Ji, S. C., Salisbury, M. H., Xia, B., Pan, M., and Xu, Z. Q.: Shear wave properties and Poisson's ratios of ultrahigh-pressure metamorphic rocks from the Dabie-Sulu orogenic belt, China: 
implications for the crustal composition, J. Geophys. Res., 110, B08208, doi:10.1029/2004JB003435, 2005b.

Wang, X. M., Liou, J. G., and Mao, H. K.: Coesite-bearing eclogites from the Dabie Mountains in central China, Geology, 17, 10851088, 1989.

Wang, Y., Xia, Y., Dong, X., Dong, H., Yang, K., Dong, Z., and Huang, L.: Quantitative analysis of two uncultured bacterial species from the terrestrial deep subsurface by real-time PCR, Acta Petrologica Sinica, 22, 2103-2106, 2006 (in Chinese with English abstract).

Wu, Y.-B., Zheng, Y. -F., Zhao, Z. F., Gong, B., Liu, X. M., and Wu, F. Y.: U-Pb, Hf and $\mathrm{O}$ isotope evidence for two episodes of fluidassisted zircon growth in marble-hosted eclogites from the Dabie orogeny, Geochim. Cosmochim. Acta, 70, 3743-3761, 2006.

Xi, D., Wan, X., Feng, Z., Li, S., Feng Z., Jia Z., Jing, X., and Si, W.: Discovery of Late Cretaceous foraminifera in the Songliao Basin: evidence from SK-1 and implications for identifying seawater incursions, Chin. Sci. Bull., 56, 253-256, 2011.

Xu, S. T., Okay, A. I., Ji, S. Y., Sengor, A. M. C., Su, W., Liu, Y. C., and Jiang, L. L.: Diamond from the Dabie Shan metamorphic rocks and its implication for tectonic setting, Science, 256, 8082, 1992.

Xu, Z. Q., Yang, W., Ji, S., Zhang, Z., Yang, J., Wang, Q., and Tang, Z.: Deep root of a continent-continent collision belt: Evidence from the Chinese Continental Scientific Drilling (CCSD) deep borehole in the Sulu ultrahigh-pressure (HP-UHP) metamorphic terrane, China, Tectonophysics, 475, 204-219, 2009a.

Xu, Z. Q., Wang, Q., Tang, Z. M., and Chen, F. Y.: Fabric kinematics of the ultrahigh-pressure metamorphic rocks from the main borehole of the Chinese Continental Scientific Drilling Project: Implications for continental subduction and exhumation, Tectonophysics, 475, 235-250, 2009b.

Xue, L., Li, H., Emily, B., Xu, Z., Kano, Y., Wang, H., Mori, J. J., Si, J., Pei, J., Zhang, W., Yang, G., Sun, Z., and Huang, Y.: Continuous permeability measurements record healing inside the Wenchuan Earthquake Fault Zone, Science, 340, 1555-1559, 2013.
Yang, J. S., Dobrzhinetskaya, L., Bai, W., Fang, Q., Robinson, P. T., Zhang, J., and Green, H. W.: Diamond- and coesite-bearing chromitites from the Luobusa ophiolite, Tibet, Geology, 35, 875878, 2007.

Yang, J. S., Robinson, P. T., and Dilek, Y.: Diamonds in ophiolites, Elements, 10, 127-130, 2014.

Yang, W. C.: The crust and upper mantle of the Sulu UHPM belt, Tectonophysics, 475, 226-234, 2009.

Zakharov, Y. D., Boriskina, N. G., Ignatyev, A. V., Tanabe, K., Shigeta, Y., Popov, A. M., Afanasyeva, T. B., and Maeda, H.: Palaeotemperature curve for the Late Cretaceous of the northwestern circum-Pacific, Cretac. Res., 20, 685-697, 1999.

Zhang, P. Z., Shen, Z. K., Wang, M., Burgmannet, R., Molnar, P., Wang, Q., Niu, Z. J., Sun, J., Wu, J., Sun, H., and You, X.: Continuous deformation of the Tibetan Plateau from global positioning system data, Geology, 32, 809-812, 2004.

Zhang, Z. M., Shen, K., Wang, J. L., and Dong, H. L.: Petrological and geochronological constraints on the formation, subduction and exhumation of the continental crust in the southern Sulu orogen, eastern-central China, Tectonophysics, 475, 291-307, 2009.

Zheng, Y.-F.: A perspective view on ultrahigh-pressure metamorphism and continental collision in the Dabie-Sulu orogenic belt, Chinese Science Bulletin, 53, 3081-3104, 2008.

Zheng, Y.-F.: Metamorphic chemical geodynamics in continental subduction zones, Chem. Geol., 328, 5-48, 2012.

Zhou, M., Robinson, T., Malpas, J., and Li, Z.: Podiform chromitites in the Luobusa ophiolite (southern Tibet): Implications for meltrock interaction and chromite segregation in the upper mantle, J. Petrol., 37, 3-21, 1996.

Zhou, Y. and Littke, R.: Numerical simulation of the thermal maturation, oil generation and migration in the Songliao Basin, Northeastern China, Mar. Pet. Geol., 16, 771-792, 1999. 